\title{
How Much Market Access? A Case study of Jordan's Exports to the $\mathrm{EU}^{*}$
}

\section{Stéphanie Brunelin, Jaime de Melo, Alberto Portugal}

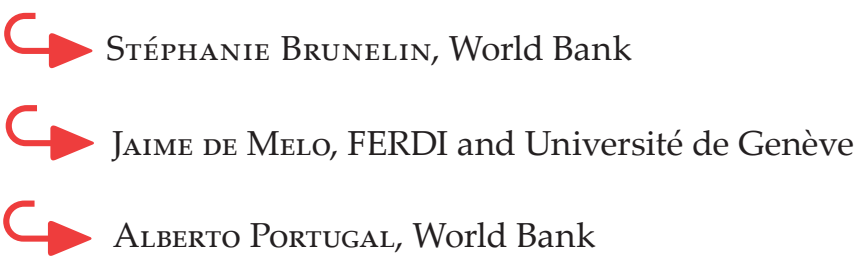

\section{Abstract}

The value of preferential market access schemes has fallen sharply. Drawing on a relaxation announcement of July 2016 simplifying origin requirements for access to the EU that should help improve market access, thereby contributing to alleviate the refugee crisis in Jordan, this paper argues that a simplification of origin requirements is a straightforward way to enhance preferential market access. Yet, the EU decision limits the beneficiaries who must be located in designated special economic zones, which limits preferential market access. The paper compares the performance of Jordanian exports to the EU and the US under their respective FTAs. It shows that Jordanian exports to the US have grown more rapidly than exports to the EU over the last fifteen years. The study documents lower utilisation of preferences in the EU than in the US, especially in Textiles and Apparel (T\&A) in spite of non-negligible preferences. Three contributing factors are identified: (i) higher adjusted preferences for apparel in the US than in the EU; (ii) greater competition from other suppliers (mostly from LDCs) in the EU market than in the US market; (iii) a simpler origin requirement in the case of the Jordan-US FTA. Comparative evidence from the two FTAs and econometric estimates suggest that this should help restore market access for Jordanian exports to the EU. These estimates provide additional evidence that origin requirements suppress market access. Other pathways to simplify origin requirements are offered in conclusion.

Keywords: Rules of origin, EU-Jordan FTA, Jordan-US FTA, preference utilization

JEL Classification: F12, F13, F15

* Without implicating them for suggestions and remaining inaccuracies, we thank Olivier Cadot, Maria-Isabel Catalan, Maria Donner Abreu, Lars Nilsson, Laurent Wagner, and Alan Winters for comments. The paper is a revised version of Brunelin, Melo and Portugal-Perez (2016). Melo gratefully acknowledges support from the French National Research Agency under program ANR-10-LABX-14-01 Findings, interpretations, and conclusions expressed in this paper are entirely those of the authors and do not reflect those of their respective institutional affiliations. 


\section{Introduction}

The value of preferential access schemes by the main purveyors of preferences, the EU and the US, has eroded over the years: a lowering of MFN tariffs, an extension of preferences by the EU and US to more countries, unpredictability often compounded by complicated origin (henceforth RoO) requirements to qualify for preferential access. Against this trend, three changes in origin requirements have sought to restore market access. In 2001, under the Africa Growth Opportunity Act (AGOA), the US announced that certain AGOA beneficiaries would satisfy the origin requirement for apparel under a minimum domestic content (i.e. fabric could be imported from third countries). This 'single transformation rule' was also adopted by the EU for Everything but Arms (EBA) beneficiaries in 2011. And, at the WTO ministerial in Nairobi in 2015, for non-reciprocal preferences for LDCs, WTO members have committed to allow that non-originating materials can make up to 75 percent of the final value of a product to qualify for preferential treatment.

Have these changes arrested the erosion of market access under preferential schemes? Market access is again at stake with the EU/friends of Jordan initiative to the Syrian refugee crisis that has resulted in Jordan hosting about 1.47 million Syrian refugees accounting for nearly 20 percent of the population by 2015. A relaxation decision (decision No.1/2016) on RoO requirements allowing, among others, for non-originating fabric in T\&A was announced for a period of 10 years in July 2016 for selected products produced in selected zones. Market access for Jordanian exports to the EU would be improved by moving to a single transformation rule in the EU-Jordan Association Agreement (the EU-Jordan FTA, henceforth EUJFTA). The decision states that it aims at creating 200,000 job opportunities for Syrian refugees.

This paper is primarily concerned with the likely effects of this initiative. We compare Jordan's current utilization of EU-preferences with the utilization of preferences by Jordanian exports to the US under the Jordan-US Free Trade Area (Jordan-US FTA, henceforth JUSFTA) which also benefits from the proposed simplified origin requirement. The paper focusses on Textiles \& Apparel (T\&A), an important export sector for Jordan and many developing countries. The paper also adds evidence on the market-access suppression effects of origin requirements in apparel.

The remainder of the paper expands on the Jordanian case study comparing performance under the EU (EUJFTA) and US (JUSFTA) FTAs (both FTAs were initiated at the same time and followed parallel paths of implementation). Section 2 describes EUJFTA and JUSFTA along two dimensions: extent of preferential market access (taking into account the erosion of preferences for Jordan from other beneficiaries of EU and US preferential schemes) and Rules of Origin (RoO) requirements. Section 3 compares the evolution of EUJFTA and JUSFTA over the ten-year period of implementation before taking a detailed look at the utilization of preferences under both FTAs in 2016. Trade patterns and utilization of preferences have been quite different in view of rather similar preferential access. Size of flows, origin requirements, and competition from other recipients of market access in the EU and the US have all contributed to these divergent outcomes. Section 4 gives econometric estimates that confirm 
several observations in section 3: Preference Utilization Rates (henceforth PURs) are positively related to preference margins. PURs are lower under EUJFTA under the doubletransformation rule than under JUSFTA where the single-transformation rule applies to apparel. Controlling for preference margins, origin requirements in apparel are independently correlated with PURs. Even though we cannot control for all factors affecting PURs in apparel, the results suggests that allowing for fabric to be imported from third countries to meet the origin requirement would help restore market access for Jordan in the EU and-more generally, contribute to arresting the erosion of market access under preferential schemes.

\section{Preferences and origin requirements under EUJ FTA and J USFTA}

Jordan is a party to several reciprocal Free Trade Area Agreements (FTAs). The two most relevant ones for evaluating trade performance are EUJFTA and JUSFTA. ${ }^{1}$ These two FTAs are the most relevant for a comparison both because the EU and the US are 'similar' along several dimensions (such as market size, tastes, and income). Also, as shown in table 3, the EU and the US have similar size markets for imports of apparel. Most importantly, the US and the EU are the only countries that report systematically PURs in their respective FTAs (and other non-reciprocal trade agreements). Jordan is also eligible for non-reciprocal market access through the Generalized System of Preferences (GSP) that generally give less market access than FTAs. The GSP is not considered further here. ${ }^{2}$

JUSFTA provided for the elimination of tariffs on all goods and services excluding tobacco and alcohol over a 10-year period starting in 2001, starting with the removal of the lowest tariffs. By 2005, tariffs over 4000 products accounting for $96 \%$ of all goods imported by the US from Jordan entered the US tariff-free (Al Nasa et al. 2008). ${ }^{3}$

\footnotetext{
${ }^{1}$ Jordan is also member of the Agadir (2006) FTA (Egypt, Jordan, Morocco, Tunisia) and the Pan African Free Trade Area (PAFTA) (1997) (Bahrain, Egypt, Iraq, Jordan, Kuwait, Lebanon, Libya, Morocco, Oman, Palestine, Qatar, Saudi Arabia, Sudan, Syria, Tunisia, UAR, Yemen) and the Canada-Jordan FTA (2012).

2 The product coverage under the GSP is usually limited and preferences fall short of duty-free entry. The GSP is specific to each grantor and, as for FTAs, GSP beneficiaries must also satisfy RoO requirements that are at least as stringent as those under FTAs.Blanchard and Hakobyan (2015) document the extensive discretion and arbitrariness in GSP market access to the US across countries, products and time. In the case of Jordan and the EU GSP, under EU GSP regulation 978/2012, Jordan is 'eligible' but not a 'beneficiary' of GSP. In the case of the US GSP, for example, Bolivia, Colombia Ecuador and Peru can export under the GSP or under the Andean Trade Preference Act (ATPA). As reported by Keck and Lendle (2012) 87\% of imports eligible under both schemes chose ATPA. This is not surprising because GSP beneficiaries are also engaged in reciprocal FTAs with GSP grantors that give them greater market access because of shorter lists of exclusions and duty-free entry. Moreover, whereas the US registers imports according to its different preferential schemes, until recently, EUROSTAT only reported imports according to two requests under two categories: MFN or preferential status. Thus, one could not distinguish between imports that might enter under the GSP from those under the EU-Jordan FTA under the assumption that the requested status was, indeed, granted (See Donner Abreu 2013, p. 26).

${ }^{3}$ Jordan has a 15 -year transition period during which it can apply temporary safeguard measure against U.S.origin imports. The Jordan-US FTA also includes measures on IPR, and not to lower environmental and labor standards. In addition to the special status of products originating from the Qualified Industrial Zones (QIZ) discussed below, USAID funds TIAJRA, a public-private sector partnership of organizations that coordinate efforts to increase the awareness and understanding of the Jordan-US FTA as well as the Jordan-U.S. Business Partnership's Export Fast Track Action Program (EFTAP). These initiatives encourage medium size Jordanian firms to learn and improve their capacity to export to the U.S.
} 
EUJFTA came into effect in 2002 with further liberalization of agricultural products in 2007 and a protocol on Dispute Settlement entered into force in 2011. Along with 15 other members, Jordan is part of the Euro-Mediterranean (EUROMED) partnership, a 'hub-andspoke' FTA in which all EUROMED have the same preferential access to the EU for nearly all products (there are a few exceptions for some agricultural products). All face the same RoO requirements, although since December 2016 for a period extending to 10 years, certain Jordanian exports face simplified RoO requirements (see below). Additionally, the EU launched negotiations for a Deep and Comprehensive FTA (DCFTA) with Jordan, Morocco, and Tunisia in 2011. The DCFTA is to include trade in services (included under the JUSFTA), government procurement, competition, intellectual property rights, and investment protection.

\subsection{Preferential margins under EUJFTA and JUSFTA}

Preferential margins provide a first measure of potential market access. Figure 1 shows the distribution of two measures of preference margins at the HS8 level: the unadjusted and the adjusted margin. The unadjusted margin is the MFN tariff minus the preferential tariff (usually zero). The adjusted preferential margin, sometimes called the 'competition-adjusted margin', subtracts from the preferential margin, the trade-weighted tariff for other recipients of preferences. The adjusted preferential margin for an HS8 product can be negative if some partners pay an MFN tariff at the HS8 level while its main competitors for the product pay less than the MFN tariff. For example, table 3 shows that China has an unadjusted preference margin of $0.0 \%$ in the US for apparel, but an adjusted margin of $(-4.0 \%)$ because other significant apparel suppliers to the US pay less than the MFN tariff.

Comparing the adjusted and unadjusted distributions in figure 1 shows that the correction for preferences granted to other recipients widens the difference in tariff shares within most ranges of the distribution. For the EU, the adjusted preferences pushes the distribution towards the $1-2.5 \%$ range but leaves the share of lines with zero tariffs at $25 \%$. For the US, the adjustment raises the percentage of zero preferential margins up to $32 \%$ from $25 \%$.

Comparing the two adjusted distributions in figure 1 shows that the EU has somewhat less preferential access to 'offer' if one concentrates on the ranges beyond the $5-10 \%$ range. The EU has a lower share of tariff lines with preferential margins in the $10-15 \%$ range and beyond (around 2\%-3\% vs. 5\% of tariff lines for the US). 
Figure 1: Distribution of Preferential tariffs for Jordanian products to US and EU (HS8)
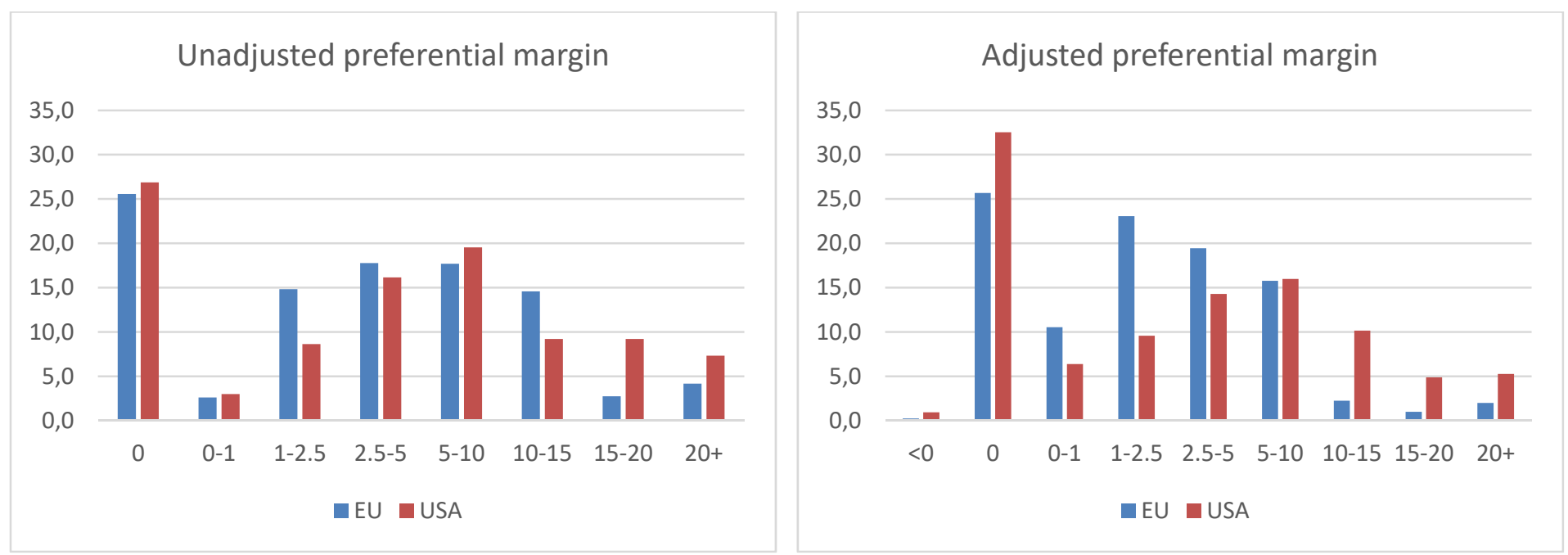

Note: See text for definition of unadjusted and adjusted preferential margins

Source: Authors' construction using data from Eurostat, USITC and TRAINS for 2016.

\subsection{Origin Requirements under EUJ FTA and J USFTA}

All preferential Trade Agreements (PTAs)--reciprocal and non-reciprocal like EverythingBut-Arms (EBA) and GSP--require establishing origin status for exports from a member country in the Agreement to prevent trans-shipment through the low-tariff partner. This is done by the application of rules of origin $(\mathrm{RoO}) .{ }^{4}$ At the same time, RoO impose costs on exporters (and importers) that have to submit the necessary documents to qualify for tariff preferences. These RoO are typically very complex and often 'made-to-measure'. The outcome is that the magnitude of these costs is difficult to assess and it is widely documented that the rather large differences in PURs around similar preference margins is a reflection of the differential costs they impose on exporters and importers. ${ }^{5}$

EU and US PTAs use a combination of methods to establish origin. Whereas RoO differ across US FTAs, almost all EU FTAs are based on the PanEuroMed (henceforth PANEURO) System, in place since 2004 (see below). Typically, establishing origin involves the combination of regime-wide rules that apply to all sectors (e.g. a roll-up or absorption principle $^{6}$ ) and a Change of Tariff Classification (CTC) at different levels (e.g. chapters or headings) across sectors. These can be coupled with a value-added criterion and, in some

\footnotetext{
4 The aim of RoO is to ensure that products involving a certain level of production within the Contracting Party benefit from the preferential treatment and thereby excluding products produced elsewhere but simply shipped via the Contracting Party to benefit from preferential access.

5 RoO requirements are known to be complicated. Thy are described in detail in Donner Abreu (2013) for a large number of PTAs. Many observers say these are "business owned" rather than "business friendly" to indicate the extent of lobbying by powerful industry groups.( See e.g. the discussion in Estevadeordal and Suominen (2006) and Cadot and Melo (2007).

${ }^{6}$ The absorption or roll-up principle allows non-originating materials, which have acquired origin by meeting specific processing requirements to maintain this origin when used as input in a subsequent transformation. The roll-up or absorption principle is used in most PTAs (See Cadot and Melo (2007 and Donner Abreu (2013)). However, article 15 of protocol 3 on RoO in PanEuroMed prohibits duty drawbacks or exemptions on nonoriginating materials.
} 
cases, like T\&A, a processing requirement. ${ }^{7}$ In the case of T\&A, JUSFTA requires minimum domestic content. Unlike most other US FTAs that require a 'yarn-forward' (or triple transformation rule), ${ }^{8}$ JUSFTA allows for fabric to be imported from third countries to meet the origin requirement provided that it undergoes substantial transformation. ${ }^{9}$

The PANEURO System, in place since 2004, covers more than 50 countries. It requires a double transformation rule. ${ }^{10}$ Jordan and other Mediterranean countries engaged in the "Barcelona process" operate under the PANEURO RoO requirements. PANEURO allows for diagonal cumulation. ${ }^{11}$ For T\&A, the standard allowance criterion that applies across sectors is replaced by an allowance in terms of weight on non-originating materials. Jordan has signed the convention that will extend regional cumulation between EUROMEDs, EFTA/Turkey/EU to the Western Balkans. ${ }^{12}$

The EU relaxation decision (decision No.1/2016) relaxed origin requirements for certain goods produced in Jordan for a ten year period until 31 December 2026. Products with relaxed rules of origin are listed in Article 2 of the Decision. The list includes petroleum products, fertilisers, some chemical and plastic products, articles of leather, textiles, and apparel. Notably, manufacture from fabric is sufficient to confer origin to Jordanian apparel. This amounts to a temporary replacement of the double transformation rule by a single transformation rule for apparel. The objective being to alleviate the Syrian refugee crisis by creating job for Syrian refugees (the decision states that the aim is to create 200,000 job opportunities for Syrian refugees), the decision only applies to goods produced in development zones and industrial areas listed in the decision. In those qualifying zones, the

\footnotetext{
${ }^{7}$ Cadot et al. (2005, table 2) describes the distribution of product-specific origin requirements at the HS6 level for NAFTA and PanEuroMed.

${ }^{8}$ Most US FTAs starting with NAFTA a triple transformation rule with fabrics (sometimes up to a certain percentage non-originating) made from yarn originating in the parties (cotton $\rightarrow$ yarn $\rightarrow$ textiles $\rightarrow$ apparel). Only qualifying African countries under AGOA and now countries under EBA have the simpler single transformation (textiles $\rightarrow$ apparel) thereby allowing third-country (i.e. non-originating) fabric. Donner Abreu (2013) compares in table 5.2 the RoO requirements in ten US FTAs showing that each is 'made-to-measure' since no two US FTAs share the same set of RoO requirements in textles.

9 The "substantial transformation" criterion requires a minimum of $20 \%$ of production for each, Jordan and Israel, excluding profits. The corresponding rule for the QIZs require 35\% regional content with $11.7 \%$ from the QIZ, 8\% from Israel and the balance from the West Bank, Gaza or a QIZ.. The main difference between the QIZ arrangement and JUSFTA is the mandatory Israeli value-added under JUSFTA. Another main difference between the two is that under the QIZ arrangement, duty- free status was immediate whereas it was progressive under JUSFTA (see below). Donner Abreu (2013, Annex 2) describes in detail the arrangements under the two protocols.

${ }^{10}$ PanEuroMed requires a "double transformation rule" (yarn $\rightarrow$ textiles $\rightarrow$ apparel), i.e. apparel made from qualifying textiles.

11 There are three cumulation rules: bilateral, diagonal and full cumulation. Bilateral cumulation is most common and applies to trade between two partners in a PTA. It stipulates that producers in country A can use inputs from country B without affecting the final good's originating status provided that the inputs are themselves originating (i.e. provided that they themselves satisfy the area's ROOs). Under diagonal cumulation (the basic principle of the EU's PANEURO system), countries tied by the same PTA as members of the "Barcelona process" can use materials that originate in any member country as if the materials were originating in the country where the processing is undertaken. Finally, under full cumulation, all stages of processing or transformation of a product within the PTA can be counted as qualifying content regardless of whether the processing is sufficient to confer originating status to the materials themselves. Full cumulation allows for greater fragmentation of the production process than diagonal cumulation, itself less restrictive than bilateral cumulation.

12 The Convention is into force but not yet into application as of end 2017 because the current protocol to the FTA is not yet replaced by a reference to the Convention.
} 
total work force of each production facility should contain at least $15 \%$ refugees in the workforce during the first and second years and at least $25 \%$ from the third year on. ${ }^{13}$

\section{Assessing EUJ FTA}

The EU and the US entered FTAs with Jordan around the same time, leading to a removal of tariffs over a ten-year period with the largest reduction in tariffs towards the end of the period around 2012. Both also had, or entered, reciprocal and/or non-reciprocal trade agreements with other partners, complicating the assessment of the effects of the two FTAs. This section compares performance under EUJFTA and JUSFTA. Section 3.1 compares the evolution of imports from Jordan over the period of implementation of the FTAs. Section 3.2 then looks at the utilization of preferences at the HS8 level for 2016. Correlates of PURs across partners are then examined in section 4.

\subsection{Trade under EUJ FTA and J USFTA}

Figure 2 shows the evolution of Jordanian exports to its principal partners with whom it has preferential trade agreements (EUJFTA, JUSFTA, PAFTA). Exports to the EU have started from a low base and have grown more slowly than exports to the other destinations. Exports to PAFTA grew rapidly until turmoil settled in the region starting around 2010 while exports to the US and the EU registered a sharp fall during the 2007-09 financial crisis. Exports to the US, when inclusive of exports originating from the Qualified Industrial Zones (QIZs) show a sharp increase starting around 2001, the first year of JUSFTA implementation. This is because exports of apparel originating from the QIZs--which have very similar RoO requirements to those under JUSFTA-- could enter the US market duty-free from the start while exports of apparel from Jordan could only enter duty-free starting in $2010^{14}$. If one excludes exports to the US from the QIZs, figure 2 shows that the growth rate of exports is the same for EUJFTA and JUSFTA until 2009. Then, exports from QIZs contract until virtually disappearing by 2014 but exports under JUSFTA continue to grow while exports under EUJFTA have stagnated over the period 2010-16.

\footnotetext{
13 The development zones are listed in the decision https://publications.europa.eu/en/publication-detail//publication/a45b2513-6e7e-11e6-b213-01aa75ed71a1/language-en

${ }^{14}$ The QIZs were introduced in 1997 as part of the US peace effort in the Middle East under the Oslo peace process. Abreu (2012, box 3.1) gives the territorial definition of the QIZ in the US Harmonized Tariff Schedule. The QIZ includes portions of the territory of Israel, and Jordan or Israel and Egypt. By 2012, there were 5 QIZs in Jordan and 4 in Egypt. Goods entering the QIZs for processing and export enter free of tariffs and taxes in the US provided they satisfy the relevant RoO
} 




Source: Author's construction using data from WITS for the EU and PAFTA, and data from USITC for USA

Annex figures A1 and A2 give more detail about the evolution of Jordanian exports to the US and the EU in the sectors that account for $90 \%$ of exports. For the US, exports are concentrated in the apparel sector. For the EU, the export basket remains far more diversified and only knitted apparel (CH61) appears in the figure. Figures A1a and A1 $\mathrm{b}^{15}$ confirm that the sharp growth in exports to the US originated from knitted apparel (HS61) and non-knitted apparel (HS62). Together, they accounted for close to $90 \%$ of Jordan's exports to the US. Figure Alb shows that exports for these two sectors originating from the QIZs fell sharply starting around 2006 when tariffs on exports of apparel from Jordan started to fall. As mentioned above, US tariffs on apparel imported from Jordan were lifted in 2010. Up until then, Jordanian exports could enter the US duty-free provided that they were declared as originating from the QIZs (and that they satisfied the QIZ RoO requirement).

Notwithstanding the end of the Multi-Fiber Agreement (MFA) in 2005, the sharp growth in exports from Jordan excluding QIZs that started around 2009 could be interpreted as an approximation of the long-run export supply elasticity to a $10 \%$ (margin adjusted) preferential rate under the prevailing RoO requirements. Figure A2 shows that exports to the EU have remained diversified and that preferential access has not resulted in a move towards a concentration of exports to the EU in labour-intensive products although one observes a growth in the share of knitted apparel (CH61) during the period 2012-2016.

In conclusion, figures A1 and A2 show that knitted (HS61) and non-knitted (HS62) apparel dominated export growth to the US but are absent from the growth of Jordanian exports to the EU. These different paths partly reflect higher preferential margins in HS61 and HS62 for the US than for the EU, but, as shown below, they also reflect other considerations including

\footnotetext{
${ }^{15}$ Appendix figures and table numbers are preceeded by an " $A$ ".
} 
greater competition from other preference-receivers on the EU than on the US side and a more lenient RoO requirement under JUSFTA. This greater competition is partly reflected in a larger discrepancy between unadjusted and adjusted margins for the EU than for the US in the textiles and apparel sector. Under JUSFTA, the adjusted preferential margins for HS61 and HS62 are about a third lower than the unadjusted rates. Under EUJFTA, the adjusted rates are about half the corresponding unadjusted rate. ${ }^{16}$ This is not surprising since the EU extended greater (and more lenient) preferences to LDCs under EBA than the US did under AGOA where membership qualification was subject to periodic review (see table 3 ).

\subsection{Preference utilization under EUJ FTA and J US FTA}

About 85 percent of world trade is registered under MFN status so trade registered under preferential status is small. ${ }^{17}$ Only the EU and the US disclose regularly the use of preferences for imported goods. ${ }^{18}$ Assuming that $\mathrm{RoO}$ requirements prevent trans-shipment, in the short to medium term, a high rate of utilization of preferences is the first yardstick to assess the intended effects of any PTA. Three factors are important in accounting for differences in PURs across sectors and eligible countries:

- The depth of preferential access captured by the preferential margin (see figure 1 and tables A2 and A3).

- The size of the shipment because of the fixed costs of complying with RoO requirements (table A4)

- The complexity of $\mathrm{RoO}$ requirements (table 3)

Table 1 compares the aggregate utilization of preferences by tranches of unadjusted (since the PUR depends on the extent of preferences) preferential margins and import value range for EUJFTA and JUSFTA for 2016. Preference Utilization Rates (PURs) are computed the HS8 level for products with a positive MFN tariff. The PUR is the share of imports entering under the preferential trade regime that complies with the RoO requirement. ${ }^{19}$ Under JUSFTA, there are no shipments in the first two bin categories of $0-10 \$$ and $10-100 \$$, but

\footnotetext{
${ }^{16}$ Tables A2 (US) and A3 (EU) show \{unadjusted\} and [adjusted] margins side by side for HS 61 and HS62 for 2016. For the US, these are: CH61: $\{16.4 \%\},[14.2 \%]$ : CH62 $\{14.3 \%\},[11.9 \%]$. The corresponding figures for the EU are: $\mathrm{CH} 61:\{11.9 \%\},[6.4 \%]$ : $\mathrm{CH} 62\{11.4 \%\},[6.1 \%]$

${ }^{17}$ Excluding intra-european trade, WTO (2011) estimates that, for the 20 largest importers accounting for $90 \%$ of world trade, only $16 \%$ of their imports from partners qualify as preferential trade (on the assumption that all preferences are fully utilized).

${ }^{18}$ In the case of the EU, Eurostat provides information on eligibility under three tariff measures (MFN,GSP, PREF) and type of requested import regime. The preference regime notified in the data is then the regime requested by the exporter, not the regime finally used. It is assumed that if an import is eligible for the regime it requested it actually obtained that regime. Donner Abreu (2013, p.26) reports that sample tests show that discrepancies between regime requests and actual registration are not significant.

${ }^{19}$ Since we do not have data on actual shipments, these averages are not import values per shipment..When some tariff lines are zero at the HS8-level and others are not, a trade-weighted average is taken.In the case of the EU, Eurostat provides information on eligibility under three tariff measures (MFN,GSP, PREF) and type of tariff (normal or under quota). See Nilsson (2011). Data by type of preference was not available, and it is assumed that if an import is eligible for the regime it requested, it actually obtained that regime. Donner Abreu (2013, p.26) reports that sample tests show that discrepancies between regime requests and actual registration are not significant.
} 
there are some shipments in these categories under EUJFTA. As one would expect, PURs under these small shipment categories are low. ${ }^{20}$

Table 1: Preference Utilization Rates (PURs) by unadjusted preferential margin and by import value range (2016)

\begin{tabular}{|c|c|c|c|c|c|c|c|c|c|}
\hline \multirow{2}{*}{\begin{tabular}{|l|} 
USA/Jordan \\
Unadjusted \\
preferential \\
margin $(\%)$
\end{tabular}} & \multicolumn{9}{|c|}{ Eligible imports (USD) } \\
\hline & $0-10$ & $10-100$ & $100-1000$ & $\begin{array}{l}1000- \\
10000\end{array}$ & $\begin{array}{l}10000- \\
100000\end{array}$ & $\begin{array}{c}100000- \\
1 \mathrm{M}\end{array}$ & $1 \mathrm{M}-10 \mathrm{M}$ & $\begin{array}{l}10 \mathrm{M}- \\
100 \mathrm{M}\end{array}$ & $100 \mathrm{M}-1 \mathrm{~B}$ \\
\hline $0-2.5$ & & & 1.00 & 0.64 & 0.87 & 0.88 & 1 & & \\
\hline $2.5-5$ & & & 0.51 & 0.63 & 0.86 & 0.92 & 0.82 & & \\
\hline $5-10$ & & & 0.56 & 0.69 & 0.82 & 0.98 & 1.00 & 1.00 & \\
\hline $10-15$ & & & 0.75 & 0.83 & 0.83 & 0.97 & 1.00 & 1.00 & \\
\hline $15-20$ & & & 0.36 & 0.60 & 0.80 & 0.82 & 1.00 & 1.00 & \\
\hline $20+$ & & & 0.00 & 0.42 & 0.59 & 0.80 & 1.00 & 1.00 & 1.00 \\
\hline EU/Jordan & \multicolumn{9}{|c|}{ Eligible imports (Euros) } \\
\hline $\begin{array}{l}\text { Unadjusted } \\
\text { preferential } \\
\text { margin }(\%)\end{array}$ & $0-10$ & $10-100$ & $100-1000$ & $\begin{array}{l}1000- \\
10000\end{array}$ & $\begin{array}{l}10000- \\
100000\end{array}$ & $\begin{array}{c}100000- \\
1 \mathrm{M}\end{array}$ & $1 \mathrm{M}-10 \mathrm{M}$ & $\begin{array}{l}10 \mathrm{M}- \\
100 \mathrm{M}\end{array}$ & $100 \mathrm{M}-1 \mathrm{~B}$ \\
\hline $0-2.5$ & 0.00 & 0.02 & 0.06 & 0.13 & 0.14 & 0.41 & 0.33 & 0.00 & \\
\hline $2.5-5$ & 0.00 & 0.08 & 0.14 & 0.26 & 0.43 & 0.35 & 0.00 & & \\
\hline $5-10$ & 0.23 & 0.15 & 0.33 & 0.56 & 0.77 & 0.81 & 0.86 & 1.00 & \\
\hline $10-15$ & 0.00 & 0.03 & 0.19 & 0.38 & 0.54 & 0.24 & 0.35 & & \\
\hline $15-20$ & 0.00 & 0.16 & 0.64 & 0.88 & 0.92 & 1.00 & 1.00 & & \\
\hline $20+$ & 0.00 & 0.20 & 0.71 & 0.81 & 0.85 & 0.86 & 1.00 & & \\
\hline
\end{tabular}

Notes: Calculations based on HS8 level data. A blank field indicates no combination in the data.

Source: Eurostat for trade data and TRAINS for tariff data for the EU; USITC for trade and tariff data for the USA.

For the import value ranges with shipments under both FTAs, for each preferential range, the PUR generally increases with the shipment value range, although there are a few exceptions to this pattern for EUJFTA and there are a few instances where the uptake is lower in the 20+ adjusted preferential margin range. This could reflect small shipments. Turn to apparel (HS 61 and 62). Under EUJFTA, the preferential margins is in the $10-15 \%$ range, while under JUSFTA, the preferential margin is in the 10-15\% range (HS61) and the 15-20\% range (HS62) (see tables A2 and A3). Note that for all import value ranges, the PUR is low in the $10-15 \%$ under EUJFTA while, on the contrary, it is high in the corresponding $10-15 \%$ and 15 $20 \%$ ranges under JUSFTA. Finally, if fixed costs are important, one would expect higher PURs in the higher import value ranges. This is generally the case, as confirmed in the

\footnotetext{
${ }^{20}$ No transactions to the US in the $\$ 0-\$ 100$ range could reflect a reporting threshold.
} 
regression results in table 4 for a larger sample of preference receivers for both the EU and US preferential schemes.

Two other patterns are apparent from the comparisons. First, PURs are high for JUSFTA for large shipment sizes. In the 1 million\$ and above ranges, with one exception, the PUR is 100 percent under JUSFTA, while this is not so for EUJFTA. Second, PURs are high in the low preferential margin $0-5.5 \%$ ranges for both FTAs, a suggestion that, on the whole, administrative costs are not high. These PURs are a very rough measure of fixed costs since one would need individual transactions rather than an average from all transactions during a year as shown in table 2. Since both the EU and US allow for self-certification, differences in fixed costs could reflect product-composition effects and differences in shipment size for which we have no data. Differences could also reflect competition from other recipients of preferences. $^{21}$

Table A1 shows PURs and adjusted preferential margins by section for 2016 for both EUJFTA and JUSFTA. The patterns confirm those in table 1. Ten of twenty-one sections have PURs of $90 \%$ or above for JUSFTA while, under EUJFTA, only five sections have PURs above $90 \%$. Several factors could account for these patterns: small value flows for the EU relative to the US that might be insufficient to cover fixed costs. ${ }^{22}$ Probably more important are the differences in origin requirements across US FTA partners.

Table 2 compares the aggregate PURs for EU and US FTAs with some Middle-East and North African countries and, in some cases, for non-reciprocal preferences under the GSP for the US. Recall that preferential access is usually the same across FTA partners so a comparison of utilization of preferences is a rough indication of effects of RoO. For EU FTAs, if one omits the Occupied Palestinian Territory Utilization, PURs are high except for Jordan (and to a lesser extent Lebanon). Since RoO requirements are the same for all EU partners (these operate under PANEURO requirements), these differences could reflect composition effects and/or fixed costs playing out differently across shipment sizes.

By contrast, in the case of the US, RoO vary across partners and, as discussed earlier, RoO requirements for Jordan for T\&A are the most lenient. Among the US FTAs, PURs are highest for Jordan, Lebanon and Egypt, which all have the single transformation rule for T\&A. ${ }^{23}$ It is noticeable that Morocco has a PUR in the US in spite of the same preferential margin as Jordan. Although it does not have an FTA with the US, Tunisia has GSP with

\footnotetext{
${ }^{21}$ Self-certification is allowed under article 23 of protocol 3 of the PanEuroMed which provides for "approved exporter" status. This status reduces fixed costs since cumbersome forms need not be filled for each shipment. Based on the construction of pseudo-transaction level data, Keck and Lendle (2012) estimate a fixed cost element in the range \$14-\$1500.

${ }^{22}$ It is likely that fewer shipments are sent to the US market than to the 28 members of the EU.

${ }^{23}$ Egypt's high preference utilization rate under GSP preferences reflects the presence of four QIZ zones in 2012 with duty-free access to the US.
} 
higher PURs than Morocco. This difference in PURs is most likely due to Morocco facing much stricter $\mathrm{RoO}$ requirement for T\&A. 24

Table 2: Preference Utilization Rates (PURs) of MFN Dutiable imports by country (2016)

\begin{tabular}{|c|c|c|}
\hline & USA & EU \\
\hline Algeria & 0.41 & 0.94 \\
\hline Egypt & 0.82 & 0.94 \\
\hline Occupied Palestinian territory & & 0.82 \\
\hline Israel & 0.84 & 0.88 \\
\hline Jordan* & 0.99 & 0.58 \\
\hline Lebanon & 0.97 & 0.69 \\
\hline Morocco & 0.59 & 0.89 \\
\hline Syria & 0.00 & 0.90 \\
\hline Tunisia & 0.68 & 0.93 \\
\hline Turkey & 0.74 & 0.92 \\
\hline
\end{tabular}

Note: * For the USA, utilization rates include FTA+ GSP+ QIZ + Civil Aircraft + pharmaceuticals

More detail is provided at the HS2 (97 chapters) level in tables A2 for JUSFTA and A3 for EUJFTA. The tables show adjusted and unadjusted margins, export volumes, and the number of HS8 observations for each chapter. Both tables show heterogeneity in PURs. Table A2 for JUSFTA confirms the 100\% PUR for apparel (HS61 and 62) which have the highest adjusted margins of $14 \%$ and $11 \%$. These two sectors also account for the bulk of imports under JUSFTA. But not all chapters with sizeable adjusted preference margins have high PURs. Of nine sectors with adjusted preferential margins of 5\% of above, tools and cutlery (HS82) has a zero PUR, headgear (HS65) has a PUR of $29 \%$ and glass and glassware (HS 70) has a PUR of $67 \%$. Both sectors account for a negligible share of US imports from Jordan. Otherwise, sectors with large import volumes like pearls and precious stones (HS 17) have high PURs even though preferential margins are not in the high range. In sum, table A2 does not give the impression of high compliance costs associated with preferences in the case of JUSFTA.

For EUJFTA, inspections of PURs and preference margins show less regularity. Some exceptions to the expected positive PUR adjusted margin relation appear for the EU in table A3. The most glaring one is for apparel (HS 61 and HS62), where the adjusted preferential margins are around 6\%--about half the corresponding rates under JUSFTA-- but the PURs are very low at 1\% (HS61) and 7\% (HS62) even though imports from both sectors are not negligible (31 and 3 million $€$ ). These low PURs stand in contrast with the PUR of $67 \%$ for HS63 (other made-up textile products for 4.4 million $€$ ). In general, however, HS categories with adjusted preferential margins in the $10 \%-25 \%$ have PURs in the $90 \%$ above range so the low PURs for apparel appear as an exception. For example, edible vegetables (HS7) has a

\footnotetext{
${ }^{24}$ The RoO for T\&A includes a yarn-forward rules coupled with a tolerance rule $(7 \%$ of weight from third parties), a diagonal rule for certain cotton fibers originating from SSA LDCs and a TPL on quantity of nonoriginating yarn and fabric. Donner Abreu table 5.2 compares RoO requirements in textiles across all US FTAs.
} 
PUR of $100 \%$ for an adjusted margin of 3.3\%. High PURs are also observed for animal fats and oils (HS15), sugars (HS17), tobacco (HS 24) which have adjusted preferential margins in the $10 \%$ or above range.

In sum, except for HS61 and HS62, the patterns of PURs in table A3 do not suggest high compliance costs under EUJFTA. However, a comparison of the top 10 recipients of (adjusted) preferential margins at the HS4 level for both countries in table A4 shows that for EUJFTA, with the exception of tobacco (HS2403), the top 10 preference-adjusted margins do not always have high PURs and all represent negligible value flows (less than 100,000€). The opposite in the case for JUSFTA. Among the top 10, all have PURs of 100 percent and most are important flows in value terms.

Competition from other suppliers might also be a reason why Jordan does not supply garments to the EU market. Table 3 shows the top 10 sources of apparel imports in 2016 for the EU and the US. Two patterns stand out. First, patterns are strikingly similar for both the US and the EU: (i) same order of magnitude among the top suppliers: (ii) a similar ranking among the top suppliers (China, Bangladesh, Vietnam): (iii) some importance for regional suppliers (Morocco and Tunisia for the EU and Mexico, Honduras and El Salvador for the US). Second, for the US, the top exporters have negative adjusted preferential margins (this is because as MFN suppliers they obtain less favourable terms than NAFTA and CAFTA_DR suppliers). Thus, compared with other suppliers in the US market, Jordan is getting as good, or better, access than competitors. On the other hand, on the EU side, Jordan is only getting better access than China, India and Vietnam. So, in effect, Jordan is competing with garments from LDCs that also enter under the single transformation rule in the EU market. 
Table 3: Top 10 sources of imports of Apparel (HS61 \& HS62) in 2016:

EU on left-hand side and US on right-hand-side

\begin{tabular}{|c|c|c|c|c|c|}
\hline EU & $\begin{array}{c}\text { Country } \\
\text { of origin }\end{array}$ & $\begin{array}{c}\text { Imports } \\
\text { (Mil. } € \text { ) }\end{array}$ & $\begin{array}{c}\text { Adj. (Unadj.) } \\
\text { Pref. margin }\end{array}$ & $\begin{array}{c}\text { Trade } \\
\text { agreement }\end{array}$ & RoO \\
\hline 1 & China & 27700 & $-8.5,(0.0)$ & MFN & NA \\
\hline 2 & Bangladesh $*$ & 14900 & $5.9,(11.9)$ & EBA & Single \\
\hline 3 & Turkey & 9513 & $5.7,(12.0)$ & CU & Double \\
\hline 4 & India & 5127 & $-4.9,(2.4)$ & GSP & Double \\
\hline 5 & Cambodia* & 3376 & $5.8,(11.9)$ & EBA & Single \\
\hline 6 & Vietnam & 2995 & $-2.9,(2.3)$ & GSP & Double \\
\hline 7 & Morocco & 2529 & $5.9,(11.8)$ & FTA & Double \\
\hline 8 & Pakistan & 2457 & $4.2,(11.8)$ & GSP+ & Double \\
\hline 9 & Tunisia & 1958 & $4.8,(11.7)$ & FTA & Double \\
\hline 10 & Sri Lanka & 1458 & $-3.3,(2.2)$ & GSP & Double \\
\hline
\end{tabular}

\begin{tabular}{|c|c|c|c|c|c|}
\hline US & $\begin{array}{c}\text { Country } \\
\text { of origin }\end{array}$ & $\begin{array}{c}\text { Imports } \\
\text { (Mil. \$) }\end{array}$ & $\begin{array}{c}\text { Adj. (Unadj.) } \\
\text { Pref. margin }\end{array}$ & $\begin{array}{c}\text { Trade } \\
\text { agreement }\end{array}$ & RoO \\
\hline 1 & China & 27900 & $-4.0,(0.0)$ & MFN & NA \\
\hline 2 & Vietnam & 10600 & $-4.6,(0.0)$ & MFN & NA \\
\hline 3 & Bangladesh* & 5100 & $-3.7,(0.0)$ & MFN & NA \\
\hline 4 & Indonesia & 4690 & $-3.7,(0.0)$ & MFN & NA \\
\hline 5 & India & 3630 & $-2.5,(0.0)$ & GSP & Triple \\
\hline 6 & Mexico & 3500 & $14.6,(18.8)$ & NAFTA & Triple \\
\hline 7 & Honduras & 2570 & $14.3,(20.5)$ & CAFTA_DR & Triple \\
\hline 8 & Cambodia* & 2140 & $-3.6,(0.0)$ & MFN & NA \\
\hline 9 & Sri Lanka & 1960 & $-3.2,(0.0)$ & MFN & NA \\
\hline 10 & El Salvador & 1920 & $14.1,(20.3)$ & CAFTA_DR & Triple \\
\hline
\end{tabular}

Note: India and Vietnam are in the process of negotiating an FTA the EU
Bangladesh has been suspended from GSP in 2013 based on failure to meet labour safety with standards.

NA stands for not-applicable, as no preferential RoO are required for MFN treatment. 


\section{Evidence on the effects of RoO requirements from other FTAs}

The comparison of PURs under EUJFTA and JUSFTA suggests that differences might at least partly, be due to differences in RoO requirements between the two FTAs, especially in the T\&A sector. This section checks if this impression holds when controlling for other factors influencing preference utilization in a larger sample of countries exporting to the EU and the US. We estimate a regression of PURs on preference margins and import volumes for all countries exporting under preferential schemes to the EU and US. The objective is to check if one can detect a Jordan and/or apparel effect. As in Keck and Lendle (2012), the following model is estimated separately for the EU and the US with 2016 data:

$$
\begin{aligned}
& u_{k, x}=\beta_{0}+\beta_{1} m_{k, x}+\beta_{2} \log \left(\operatorname{eligm}_{k, x}\right)+\beta_{3} \text { jor }_{k, x}+\beta_{4}(t \& a)_{k, x}+\beta_{5}\left(\text { jor }_{k, x}\right)(t \& a)_{k, x} \\
& +\beta_{6} \operatorname{Agr}_{k, x}+\gamma_{x}+\varepsilon_{k, x} \text { (1) ; } u_{k, x}=\frac{\operatorname{pref}_{k, x}}{\operatorname{elig}_{k, x}} ; m_{k, x}=t_{k}-t p_{k, x} ; k=1 . . H S 8 ; x=
\end{aligned}
$$

$1 \ldots n$

In (1), $u_{k, x}$ is the use of preferential access on imports of product $k$ (at HS8 level) by country $x ; m_{k, x}$ is the unadjusted preferential margin defined as the difference between the MFN tariff and the lowest preferential rate available for country $x$; $\operatorname{eligm}_{k, x}$ is the value of eligible imports of product $k$ from country $x$; jor $r_{k, x}$ is a dummy variable equal to one if exporter $x$ is Jordan and zero otherwise; $(t \& a)_{k, x}$ is a dummy equal to one if product $k$ is in the apparel sector; $\gamma_{x}$. is a country dummy. Equation (1) is estimated separately for the US and the EU because there is no concordance for products defined at the HS8-level. ${ }^{25}$ Country dummies are included to control for heterogeneity.

The estimations are restricted to the products eligible for preferential treatment, i.e. products with zero MFN tariffs and products excluded from the preferential regimes are not considered. The PUR is the ratio of imports entering under preferential treatment to total imports of the product eligible for preferences (i.e. to imports with a positive MFN tariff). We expect $u_{k, x}$ to be positively correlated with both a higher preferential margin $\left(\beta_{1}>0\right)$ and with a higher import volume $\left(\beta_{2}>0\right)$ because of fixed costs. If costs associated with RoO are purely variable costs, the utilization should only vary with the preferential margin. It should be independent of the volume when controlling for the margin. A coefficient $\left(\beta_{3}>0, \beta_{3}<\right.$ 0 ) would capture a positive (negative) Jordan effect and, when interacted with apparel $\left(\beta_{5}>0\right.$ or $\left.\beta_{5}<0\right)$, the coefficient would capture the effect of differences in RoO. The dummy variable for agriculture captures the possibility that meeting origin requirements should be easier as the 'wholly obtained' origin requirement is likely straightforward to implement $\left(\beta_{6}>0\right)$

\footnotetext{
${ }^{25}$ HS-6 is the most disaggregated international common classification. Data at.the HS-8 classification is different for each importer, so regressions are reported separately for the EU and US. In addition, the US database reports actual preferential imports, whereas in the EU database reports imports requested under a preferential regime. For more details consult Larsson (2011).
} 
When computed at the transaction level, the preferential utilization is either 0 (the product eligible for preferential treatment is imported under the MFN regime) or 1 (the eligible product is imported under the preferential trade regime). As we do not have access to transaction level data, preferential utilization rates range between 0 and 1 when computed at the HS-8 level. As the dependent variable is the proportion of eligible imports that enter under preferential regimes, it is a continuous variable bounded by 0 and 1 . Then the OLS linear regression is unsuitable. Hence, we use the fractional logit model as suggested by Keck and Lendle (2012) but also report OLS and Tobit estimates for comparison with other estimates.

\subsection{Results}

To save space, we only report one set of results since results across specifications are close. For each of the EU and US, we report an OLS, a TOBIT and a fractional logit. ${ }^{26}$ First, as expected, PURs are positively associated with the preferential margin $\left(\beta_{1}>0\right)$. Second, as in Keck and Lendle (2012) the dummy for agriculture is positive and significant for both specifications. Third, as in Keck and Lendle, controlling for the margin, a higher import volume is associated with a higher PUR, $\left(\beta_{2}>0\right)$ an indication of fixed costs. Fourth, expected, the dummy for Jordan is positive for both the EU and the US, but of larger magnitude for the US. This difference in coefficient values suggests that Jordanian exports are more competitive in the US than in the EU. Finally, the interaction of the dummy for Jordan with the dummy for T\&A is positive for the US and negative for the EU. In the EU market for T\&A, LDCs benefit from the single transformation rule since 2011 while Jordan still operated under a double transformation rule in 2016. On the other hand, in the US market for T\&A, most competitors operate under the yarn-forward (triple transformation) rule while Jordan operates under the single transformation rule. Together, these results point towards the origin requirement in T\&A having an independent effect on the utilization of preferences in T\&A.

\footnotetext{
${ }^{26}$ Marginal effects for the fractional logit could only be obtained when replacing country dummies by regional dummies. Similar estimates are obtained from a pooled sample comprising EU and US imports with common HS-8 categories. Results available from the authors upon request.
} 
Table 4: Correlates of utilization of preferences on EU and US markets (2016)

(Dependent variable: preference utilization rate)

\begin{tabular}{|c|c|c|c|c|c|c|}
\hline & \multicolumn{3}{|c|}{ EU estimates } & \multicolumn{3}{|c|}{ USA estimates } \\
\hline & OLS & Tobit & GLM & OLS & Tobit & GLM \\
\hline \multirow{2}{*}{ Log(Imports) } & $0.06 * * *$ & $0.11 * * *$ & $0.32 * * *$ & $0.03 * * *$ & $0.04 * * *$ & $0.17 * * *$ \\
\hline & $(0.000)$ & $(0.001)$ & $(0.002)$ & $(0.001)$ & $(0.001)$ & $(0.004)$ \\
\hline \multirow{2}{*}{ Preference margin } & $0.01 * * *$ & $0.02 * * *$ & $0.06^{* * *}$ & $0.00 * * *$ & $0.01 * * *$ & $0.03 * * *$ \\
\hline & $(0.000)$ & $(0.000)$ & $(0.003)$ & $(0.000)$ & $(0.001)$ & $(0.003)$ \\
\hline \multirow{2}{*}{ Agriculture } & $0.22 * * *$ & $0.47 * * *$ & $1.14 * * *$ & $0.23 * * *$ & $0.63^{* * *}$ & $1.63^{* * *}$ \\
\hline & $(0.004)$ & $(0.010)$ & $(0.032)$ & $(0.006)$ & $(0.016)$ & $(0.053)$ \\
\hline \multirow{2}{*}{ Jordan } & $0.05 * *$ & $0.18 * * *$ & 0.28 & $0.35 * * *$ & $0.80 * * *$ & $1.61 * * *$ \\
\hline & $(0.023)$ & $(0.063)$ & $(0.169)$ & $(0.053)$ & $(0.122)$ & $(0.356)$ \\
\hline \multirow{2}{*}{ Textile and Apparel } & $0.01 * * *$ & -0.00 & $-0.04^{*}$ & -0.01 & $-0.07 * * *$ & $-0.12 * * *$ \\
\hline & $(0.003)$ & $(0.007)$ & $(0.024)$ & $(0.006)$ & $(0.014)$ & $(0.036)$ \\
\hline \multirow{2}{*}{ Jordan*T\&A } & $-0.17 * * *$ & $-0.38 * * *$ & $-1.21 * * *$ & $0.13 * * *$ & $0.21 * *$ & $0.96 * * *$ \\
\hline & $(0.028)$ & $(0.074)$ & $(0.246)$ & $(0.037)$ & $(0.089)$ & $(0.279)$ \\
\hline \multirow{2}{*}{ Constant } & $-0.29 * * *$ & $-1.42^{* * *}$ & $-4.60 * * *$ & 0.05 & $-0.26^{* *}$ & $-2.55^{* * *}$ \\
\hline & $(0.020)$ & $(0.057)$ & $(0.152)$ & $(0.047)$ & $(0.107)$ & $(0.321)$ \\
\hline Country dummies & Yes & Yes & Yes & Yes & Yes & Yes \\
\hline Observations & 117,851 & 117,851 & 117,852 & 50,540 & 50,540 & 50,541 \\
\hline
\end{tabular}

Robust standard errors in parentheses. Significance level: ${ }^{* * *} \mathrm{p}<0.01,{ }^{* *} \mathrm{p}<0.05,{ }^{*} \mathrm{p}<0.1$ 


\section{Conclusions.}

This paper reviewed trade under EUJFTA and JUSFTA, two FTAs initiated under similar circumstance over comparable periods. The comparisons show higher growth of imports under JUSFTA than under EUJFTA and, as of 2016, a higher utilization of preferences under JUSFTA than under EUJFTA, especially in the apparel sector where import volumes from Jordan to the US are much higher than those to the EU. For other sectors, preference utilization rates (PURs) follow similar patterns rising with the preference margin and average volumes. For the apparel sector, under EUJFTA, the PUR is in the 1-7\% range for an adjusted preferential margin of $6 \%$ while under JUSFTA, the PUR is at $100 \%$ for an adjusted margin in the $12 \%-14 \%$ range. Three factors combine to induce this stark contrast. A higher preferential margin for the US, more competition from other (mostly LDCS) suppliers in the EU market, and a single transformation rule for T\&A under JUSFTA.

This very different performance under the two FTAs amply justifies the relaxation decision (decision No.1/2016) announced in July 2016 by which market access of Jordanian exports to the EU will be improved by moving to a single transformation rule. However, since LDCs also access the EU market under a single transformation rule, in the end, this announcement may only have limited effects on Jordanian exports to the EU. In addition, the EU decision also limits the beneficiaries who must be located in designated special economic zones which could be equivalent to a quota on exports under a capacity constraint eligible for preferential market access. Indeed, companies operating outside the designated areas will have to incur costs to move operations if they want to benefit from preferences. In addition, the conflict in neighboring Syria has disrupted land transport through the country towards Syrian and Lebanese ports, leaving the port of Aqaba in the south of Jordan as the viable option for Jordanian merchandises. Yet, inland transport to the Aqaba port from many of the designated special economic zones is very costly.

Beyond the refugee crisis, other simplifications in origin requirements would also be welcome to restore market access under preferential schemes. Eliminating RoO requirements for tariff lines with unadjusted preferential margins below 3\% --which corresponds to the middle range of estimates of fixed costs, at least for small firms (see Cadot and Melo (2007) and Keck and Lendle (2012)). A uniform low value content rule (say 20\% value-added across-the-board) perhaps combined with a Change of Tariff Classification (CTC) at the subheading (HS6) level could also be envisaged. Alternatively, the CTC might be at the heading level, while for $\mathrm{T} \& \mathrm{~A}$, it could be accompanied by a lower value-content rule for apparel, which has shown to be responsive to preferences under the Jordan-US FTA.

\section{References}

Al Nasa's, M., J. Chin, S. Leonard, C. Munoz, B. Reilly (2008) “The Jordan-U.S. Free Trade Agreement: Eight Years Later", mimeo, University of Michigan 
Blanchard, E. and S. Hakobyan (2015) "The US Generalised System of Preferences in Principle and Practice", The World Economy,

Brunelin, Stéphanie, Jaime de Melo and Alberto Portugal-Perez (2016) "Improving Market Access for Jordanian Exports", FERDI WP\#169

http://www.ferdi.fr/sites/www.ferdi.fr/files/publication/fichiers/p169-ferdi-brunelin _demelo - portugal.pdf

Cadot, O., A. Estevadeordal, A. Suwa-Eisenmann and Thierry Verdier eds. (2006) The Origin of Goods: Rules of Origin in Regional Trade Agreements, Oxford U. Press

Cadot, O., C. Carrère, J. de Melo and A. Portugal-Perez (2005) "“"Market Access and Welfare Under Free Trade Agreements: Textiles under NAFTA", The World Bank Economic Review, vol. 19(3): 379-405

Cadot, O. and J. de Melo (2007), "Why OECD Countries Should Reform their Rules of Origin”, World Bank Research Observer, 77-105

Conconi, P., M. Garcia-Santana, L. Puccio, R. Venturini (2016) « From Final Goods to inputs: the Protectionist Effect of Rules of Origin", CEPR \#11084

Donner Abreu, M. (2013) "Preferential Rules of Origin in Regional Trade Agreements", ERSD-2013-05, WTO,

Estevadeordal, A. and K. Suominen (2006), "Mapping Rules of Origin Around the World" chp. 3 in O. Cadot et al. eds, pp. 69-113.

EU Commission (2014) "Guide to the Pan-Euro-Mediterranean Origin Protocols",

Keck, Alexander and Andreas Lendle (2012) "New Evidence on Preference Utilization", ERSD-2012-12

Melo, J. de and A. Portugal-Perez (2014) "Rules of Origin, Preferences and Diversification in Apparel: African Exports to the US and to the EU', World Bank Economic Review, 28(1), 7498

Nilsson, Lars (2011) "Principles of EU Imports, Tariffs and Tariff Regimes", Journal of World Trade, 45(4), 821-35

Portugal-Perez, A. (2011) "Assessing the Political Economy Factors on Trade Integration: Rules of Origin under NAFTA," Journal of Economic Integration, vol. 26, pages 276-305.

World Trade Organization (2011) World Trade Report: The WTO and Preferential Trade Agreements: From Co-existence to coherence 
Annex to

ImprovingMarket Access for Developing Countries: A Casestudy ofJ ordan's Exports to the EU*

Stéphanie Brunelin§ , J aime de Melo*, Alberto Portugal

February 26, 2018

Figure A1: US imports from Jordan by HS2 category 2002-16 (90\% of yearly trade)

a) including imports from QIZs

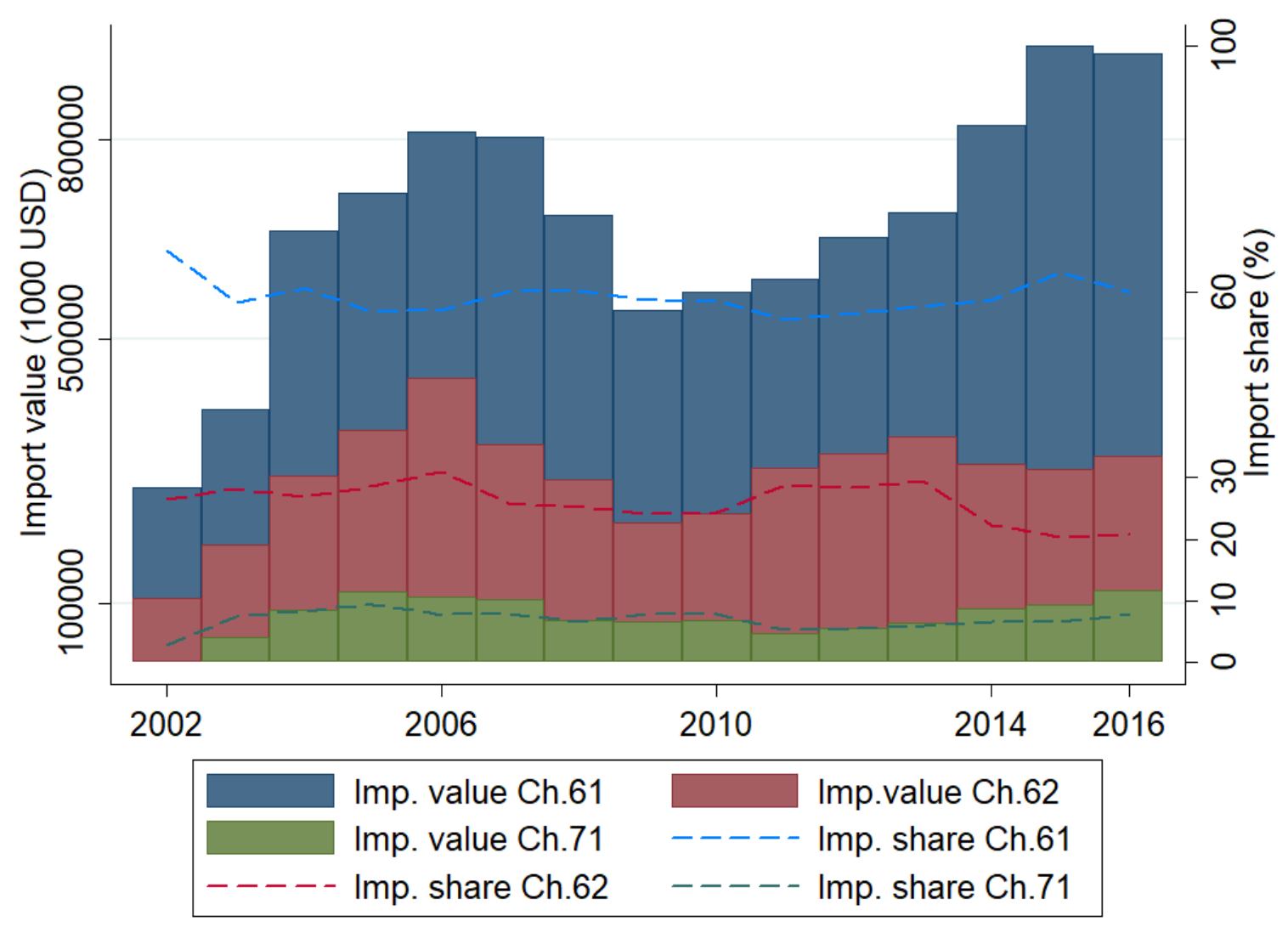




\section{b) excluding imports from QIZs}

* Available at http://www.ferdi.fr/sites/www.ferdi.fr/files/publication/fichiers/p169-ferdi-brunelin demelo - portugal.pdf

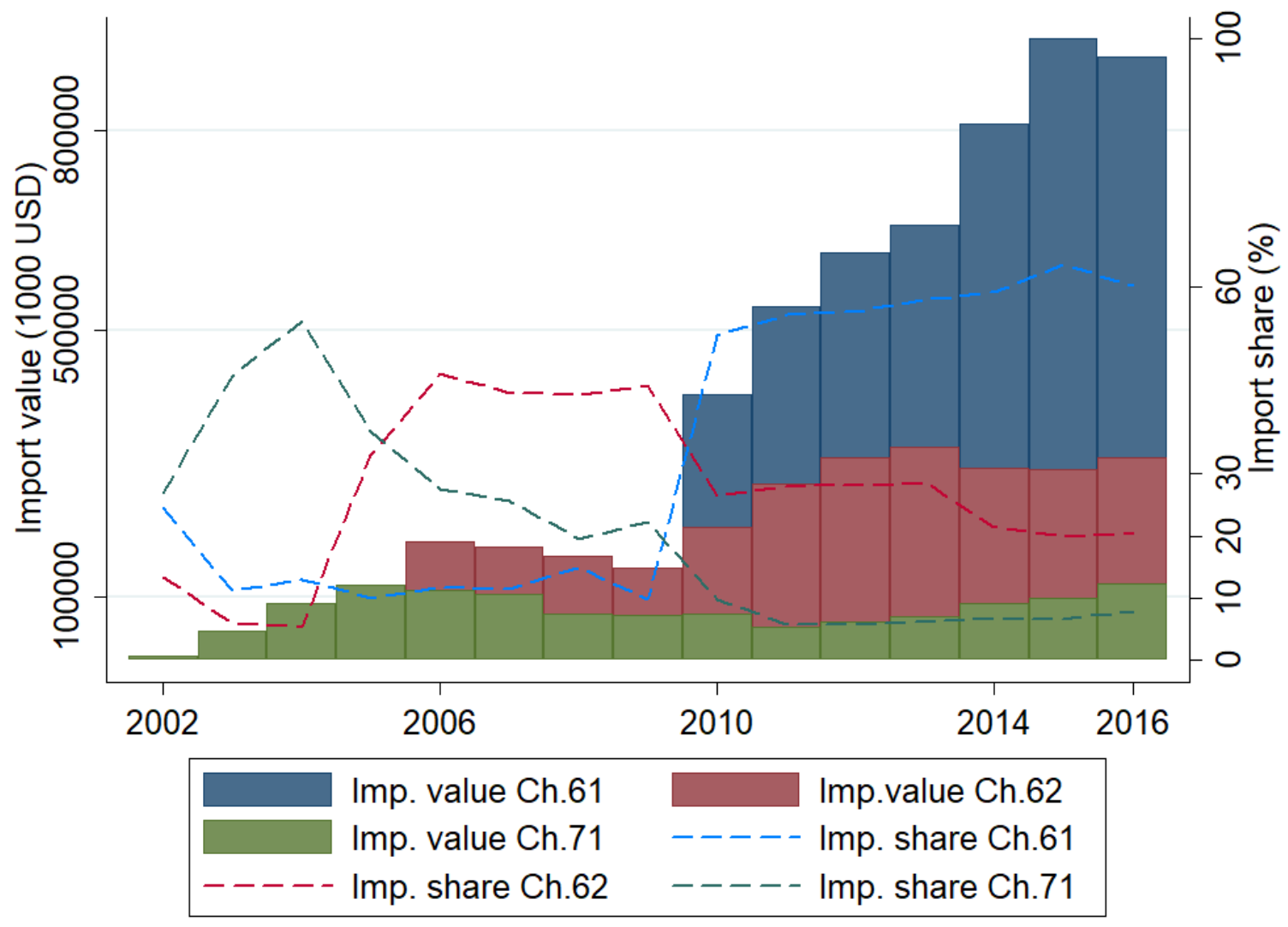

Notes: Boxes represent dollar values and dashed lines the corresponding import shares. Source: USITC for figure A1a and A1b

CH 61: Apparel \& Clothing, knitted or crocheted

CH 62: Apparel \& Clothing, not knitted or crocheted

CH72: Iron \& Steel 
Figure A2: EU imports from Jordan by HS2 category 2002-16 (90\% of trade in 2016)

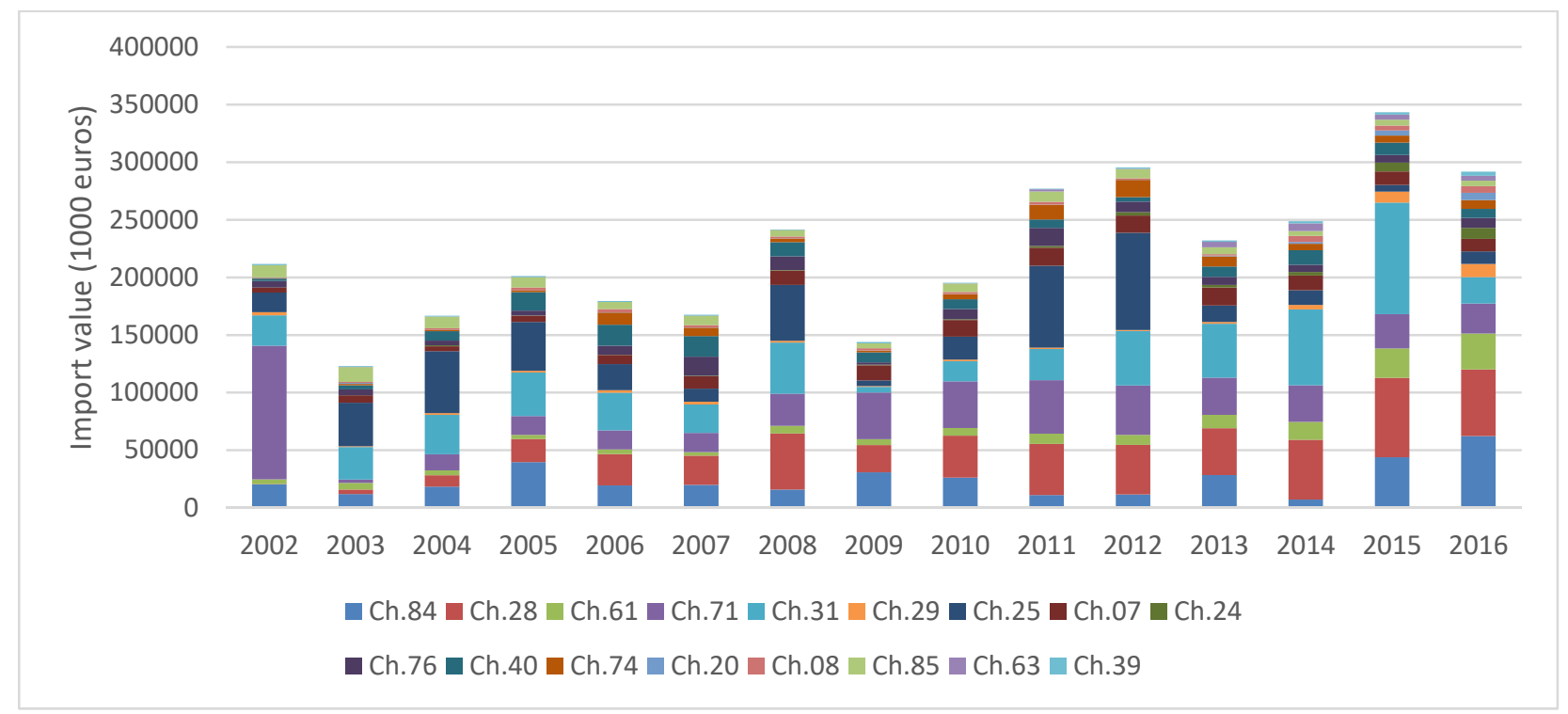

Source: Eurostat

CH 84: Nuclear reactors, boilers

CH 28: Inorganic chemicals

CH 61: Apparel \& clothing, knitted or crocheted

CH 71: Pearls, precious stones, precious metals

CH 31: Fertilisers

CH 29: Organic chemicals

CH 25: Salt, sulphur, lime \& cement

CH 07: Edible vegetables and tubers

CH 24: Tobacco

CH 76: Aluminium \& articles

CH 40: Rubber and articles thereof

CH 74: Copper \& articles

CH 20: Preparations of vegetable, fruit, nuts or other parts of plants

CH 08: Coffee, tea, mate and spices

CH 85: Electrical machinery \& equipment

CH 63: Other made-up textile articles; sets; worn clothing and worn textile articles; rags

$\mathrm{CH}$ 39: Plastics and articles thereof 
Table A1: Utilization rates of MFN dutiable imports from Jordan by section (2016)

\begin{tabular}{|c|c|c|c|c|}
\hline & \multicolumn{2}{|c|}{ JUSFTA } & \multicolumn{2}{|c|}{ EUJFTA } \\
\hline & $\begin{array}{l}\text { Utilization } \\
\text { rate }\end{array}$ & $\begin{array}{c}\text { Adjusted } \\
\text { preferential } \\
\text { margin }\end{array}$ & $\begin{array}{l}\text { Utilization } \\
\text { rate }\end{array}$ & $\begin{array}{c}\text { Adjusted } \\
\text { preferential } \\
\text { margin }\end{array}$ \\
\hline Section I : Live animals, animal products & 100 & 4.3 & 0 & 2.9 \\
\hline Section II: Vegetable products & 91 & 0.8 & 95 & 5.6 \\
\hline Section III: Animal or vegetable fats and oils, animal or vegetable waxes & 100 & 1.2 & 94 & 17.4 \\
\hline Section IV: Prepared foodstuffs, beverages, spirits and vinegard; tobacco & 99 & 2.0 & 96 & 8.0 \\
\hline Section V: Mineral products & & 0 & 95 & 0.5 \\
\hline Section VI: Products of the chemical or allied industries & 27 & 0.5 & 90 & 1.9 \\
\hline Section VII: Plastics and articles thereof; rubber and articles thereof & 38 & 1.9 & 28 & 3.3 \\
\hline Section VIII: Raw hides, skins \& leather; articles of leather; furskins \& artificial fur & 80 & 8.4 & 54 & 1.9 \\
\hline Section IX: Wood products; cork products; manufactures of straw & 78 & 4.0 & 39 & 0.7 \\
\hline Section X: Pulp of wood cellulosic material; paper \& paperboard; printed books & & 0 & & 0.0 \\
\hline Section XI: Textiles and apparel articles & 100 & 12.0 & 12 & 6.0 \\
\hline Section XII: Footwear; headgear; umbrellas: feathers \& down & 41 & 5.8 & 0 & 4.9 \\
\hline Section XIII: Articles of stone, plaster, cement; ceramic products; glass \& glassware & 93 & 5.1 & 49 & 3.2 \\
\hline Section XIV: Pearls, precious stones, precious metals & 100 & 4.1 & 83 & 1.3 \\
\hline Section XV: Base metals and articles of base metal & 94 & 1.3 & 71 & 1.8 \\
\hline Section XVI: Nuclear reactors, boilers; electrical machinery \& equipment & 98 & 0.6 & 1 & 1.2 \\
\hline Section XVII: Vehicles, aircraft, vessel and associated transport equipment & 8 & 1.0 & 12 & 3.0 \\
\hline $\begin{array}{l}\text { Section XVIII: Optical, photographic, medical instruments; clocks \& watches, musical } \\
\text { instruments }\end{array}$ & 12 & 0.2 & 0.1 & 0.8 \\
\hline Section XX: Miscellaneous manufactures articles & 100 & 0.6 & 39 & 2.1 \\
\hline Section XXI: Works of art & & 0 & & 0 \\
\hline Total & & & & \\
\hline
\end{tabular}

Source: Eurostat for trade data and TRAINS for tariff data for the EU; USITC for trade and tariff data for the USA. 


\begin{tabular}{|c|c|c|c|c|c|c|c|}
\hline HS2 & Description & $\begin{array}{l}\text { Utilization } \\
\text { rate }\end{array}$ & $\begin{array}{l}\text { Unadjusted } \\
\text { preferential } \\
\text { margin }\end{array}$ & $\begin{array}{c}\text { Adjusted } \\
\text { preferential } \\
\text { margin }\end{array}$ & $\begin{array}{l}\text { Imports } \\
\text { (1000USD) }\end{array}$ & $\begin{array}{l}\text { Import } \\
\text { share } \\
(\%)\end{array}$ & $\begin{array}{c}\text { Nb } \\
\text { obs } \\
\text { HS8 }\end{array}$ \\
\hline 1 & Live animals & & 0.00 & 0.00 & 3 & 0.00 & 1 \\
\hline 2 & Meats & & & & & & 0 \\
\hline 3 & Fish & & & & & & 0 \\
\hline 4 & Dairy produce; birds' eggs; natural honey & 1.00 & 8.68 & 5.01 & 234 & 0.02 & 6 \\
\hline 5 & Products of animal origin, NES & & & & & & 0 \\
\hline 6 & Live trees \& other plants & & & & & & 0 \\
\hline 7 & Edible vegetables and tubers & 0.77 & 2.83 & 1.38 & 72 & 0.00 & 6 \\
\hline 8 & Edible fruits \& nuts & & & & & & 0 \\
\hline 9 & Cofee, tea, maté and spices & 0.96 & 1.88 & 1.14 & 2151 & 0.15 & 16 \\
\hline 10 & Cereals & 1.00 & 1.78 & 0.09 & 6 & 0.00 & 1 \\
\hline 11 & Products of the milling industry & 1.00 & 4.50 & 0.02 & 8 & 0.00 & 1 \\
\hline 12 & Oil seeds and oleaginous fruits & 0.88 & 0.85 & 0.38 & 1417 & 0.10 & 13 \\
\hline 13 & Lac; gums, resins and extracts & & 0.00 & 0.00 & 14 & 0.00 & 2 \\
\hline 14 & Vegetable plaiting materials & & & & & & 0 \\
\hline 15 & Animal or vegetable fats and oils & 1.00 & 1.53 & 1.17 & 517 & 0.03 & 9 \\
\hline 16 & Meat of fish or of crustaceans & & & & & & 0 \\
\hline 17 & Sugars and sugar confectionery & 0.96 & 6.13 & 2.49 & 469 & 0.03 & 9 \\
\hline 18 & Cocoa \& cocoa preparations & 1.00 & 3.05 & 0.72 & 280 & 0.02 & 7 \\
\hline 19 & Cereals, flour, starch or milk & 0.99 & 6.30 & 1.52 & 3228 & 0.22 & 16 \\
\hline 20 & Vegetables, fruits, plants & 1.00 & 6.16 & 3.20 & 2254 & 0.15 & 28 \\
\hline 21 & Miscellaneous edible & 0.99 & 7.09 & 2.92 & 2142 & 0.14 & 21 \\
\hline 22 & Beverages, spirits and vinegar & 0.98 & 0.29 & 0.26 & 222 & 0.01 & 5 \\
\hline 23 & Residues food industries & & & & & & 0 \\
\hline 24 & Tobacco & & 0.00 & -0.53 & 6104 & 0.41 & 9 \\
\hline 25 & Salt; sulphur, lime \& cement & & 0.00 & 0.00 & 42 & 0.00 & 4 \\
\hline 26 & Ores, slag and ash & & & & & & 0 \\
\hline 27 & Mineral fuels, mineral oils & & 0.00 & 0.00 & 4 & 0.00 & 1 \\
\hline 28 & Inorganic chemicals & & 0.00 & 0.00 & 5171 & 0.35 & 4 \\
\hline 29 & Organic chemicals & & & & & & 0 \\
\hline 30 & Pharmaceutical products & & 0.00 & 0.00 & 38800 & 2.62 & 4 \\
\hline 31 & Fertilisers & & 0.00 & 0.00 & 7 & 0.00 & 1 \\
\hline 32 & Tanning, paints and varnishes & 0.00 & 3.40 & 3.29 & 8 & 0.00 & 1 \\
\hline 33 & Essential oils and resinoids & 1.00 & 1.40 & 0.68 & 450 & 0.03 & 11 \\
\hline 34 & Soap & & 0.00 & 0.00 & 2135 & 0.14 & 3 \\
\hline 35 & Albuminoidal substances & & & & & & 0 \\
\hline 36 & Explosives, pyrotechnic products & & & & & & 0 \\
\hline 37 & Photographic & & 0.00 & 0.00 & 9 & 0.00 & 1 \\
\hline 38 & Miscellaneous chemicals & 0.12 & 3.83 & 0.92 & 34 & 0.00 & 3 \\
\hline 39 & Plastics & 0.38 & 4.04 & 2.11 & 2984 & 0.20 & 33 \\
\hline 40 & Rubber and articles & 0.06 & 2.48 & 1.21 & 26 & 0.00 & 6 \\
\hline 41 & Raw hides and skins \& leather & & & & & & 0 \\
\hline 42 & Articles of leather & 0.80 & 9.42 & 8.39 & 11 & 0.00 & 7 \\
\hline 43 & Furskins and artificial fur & & & & & & 0 \\
\hline
\end{tabular}


Wood products

Cork products

Manufactures of straw

Pulp of wood cellulosic material

Paper and paperboard

Printed books, newspapers

Silk

Wool, fine or coarse animal hair

Cotton

1.00

Other vegetable textile fibres

Man-made filaments

Man-made staple fibres

Wadding, felt and nonwovens

Carpets and other textile floor

Special woven fabrics

Impregnated, coated

Knitted or crocheted fabrics

Apparel \& clothing, knitted or crocheted

Articles of apparel \& clothing, not knitted or crocheted

Other made-up textiles articles

Footwear

Headgear

Umbrellas

Feathers \& down

Articles of stone, plaster, cement

Ceramic products

Glass and glassware

Pearls, precious stones, precious metals

Iron and steel

Articles of iron or steel

Copper \& articles

Nickel \& articles

Aluminium \& articles

Lead \& articles

Zinc \& articles

Tin \& articles

Other base metals

Tools, cutlery, of base metal

Miscellaneous articles of base metal

Nuclear reactors, boilers

Electrical machinery \& equipment

Railway or tramway locomotives

Vehicles other than railway

Aircraft, spacecraft \& parts

Ships, boats \& floating structures

Optical, photographic, medical instruments

Clocks and watches and parts thereof

Musical instruments

0.52

1.00

1.00

0.98

0.29

1.00

0.95

0.84

0.67

1.00

0.48

1.00

0.00

0.99

0.08

0.23
0.87

3.50

0.00

0.00

6.50

6.41

50

0.00

1.55

0.00

16.45

14.26

9.72

7.57

4.70

3.94

7.07

7.13

7.20

1.64

2.90

0.84

0.06

2.96

2.19

6.41

6.70

4.08

1.31

801

0.00

65

10

0.00

930000

62.81

21.74

$0.38 \quad 12$

5558

0.00

3

0

$\begin{array}{lll}3 & 0.00 & 1\end{array}$

478

$0.03 \quad 13$

$\begin{array}{lll}73 & 0.00 & 11\end{array}$

149

$0.01 \quad 8$

21000

$8.14 \quad 20$

$0.05 \quad 10$

0.00

6.22

0.00

5.68

0.85

0.56

1.52

1.81

0.67

1.67

1.00

720

22

0.00

0.00

0.60

0.23

0.00

0.00

0




\begin{tabular}{|c|c|c|c|c|c|c|c|}
\hline 93 & Arms and ammunitions & & & & & & 0 \\
\hline 94 & Furniture; bedding mattresses & 1.00 & 1.07 & 0.79 & 345 & 0.02 & 19 \\
\hline 95 & Toys, games and sports requisites & & 0.00 & 0.00 & 26 & 0.00 & 6 \\
\hline 96 & Miscellaneous manufactured articles & 1.00 & & & 435 & 0.03 & 4 \\
\hline 97 & Works of art & & 0.00 & 0.00 & 1041 & 0.07 & 9 \\
\hline
\end{tabular}

Source: USITC for trade and tariff data. Note: Blanks indicate that all imports in the HS category have zero MFN duties. 


\begin{tabular}{|c|c|c|c|c|c|c|c|}
\hline $\begin{array}{c}\text { HS } \\
2\end{array}$ & Description & $\begin{array}{c}\text { Utilization } \\
\text { rate }\end{array}$ & $\begin{array}{c}\text { Unadjusted } \\
\text { pref. } \\
\text { margin }\end{array}$ & $\begin{array}{l}\text { Adjusted } \\
\text { pref. } \\
\text { margin }\end{array}$ & $\begin{array}{l}\text { Imports } \\
(1000 \\
\text { Euros) }\end{array}$ & $\begin{array}{l}\text { Import } \\
\text { share } \\
(\%)\end{array}$ & $\begin{array}{c}\text { Nb } \\
\text { obs } \\
\text { HS8 }\end{array}$ \\
\hline 1 & Live animals & 0.00 & 3.83 & 3.16 & 16 & 0.00 & 4 \\
\hline 2 & Meats & & & & & & \\
\hline 3 & Fish & & 0.00 & -7.15 & 2 & 0.00 & 2 \\
\hline 4 & Dairy produce; birds' eggs; natural honey & 0.00 & 25.14 & 7.71 & 0 & 0.00 & 4 \\
\hline 5 & Products of animal origin, NES & & & & & & \\
\hline 6 & Live trees \& other plants & 0.54 & 5.68 & 1.05 & 3 & 0.00 & 7 \\
\hline 7 & Edible vegetables and tubers & 1.00 & 9.52 & 3.35 & 10881 & 3.31 & 120 \\
\hline 8 & Edible fruits \& nuts & 0.90 & 6.58 & 2.01 & 5816 & 1.77 & 61 \\
\hline 9 & Cofee, tea, maté and spices & 0.98 & 2.62 & 0.53 & 940 & 0.29 & 131 \\
\hline 10 & Cereals & 0.96 & 24.12 & 13.23 & 62 & 0.02 & 14 \\
\hline 11 & Products of the milling industry & 0.95 & 31.77 & 21.99 & 34 & 0.01 & 32 \\
\hline 12 & Oil seeds and oleaginous fruits & 0.61 & 0.95 & 0.62 & 720 & 0.22 & 30 \\
\hline 13 & Lac; gums, resins and extracts & 0.00 & 5.60 & 1.17 & 13 & 0.00 & 7 \\
\hline 14 & Vegetable plaiting materials & & 0.00 & 0.00 & 6 & 0.00 & 4 \\
\hline 15 & Animal or vegetable fats and oils & 0.94 & 25.01 & 17.42 & 1959 & 0.60 & 31 \\
\hline 16 & Meat of fish or of crustaceans & 0.00 & 48.54 & 34.70 & 0 & 0.00 & 2 \\
\hline 17 & Sugars and sugar confectionery & 0.91 & 18.53 & 11.99 & 770 & 0.23 & 53 \\
\hline 18 & Cocoa \& cocoa preparations & 0.98 & 11.03 & 5.60 & 29 & 0.01 & 17 \\
\hline 19 & Cereals, flour, starch or milk & 0.96 & 13.56 & 7.04 & 1041 & 0.32 & 85 \\
\hline 20 & Vegetables, fruits, plants & 0.97 & 18.58 & 8.13 & 6314 & 1.92 & 179 \\
\hline 21 & Miscellaneous edible & 0.92 & 9.19 & 4.32 & 1072 & 0.33 & 69 \\
\hline 22 & Beverages, spirits and vinegar & 0.83 & 3.77 & 1.49 & 494 & 0.15 & 64 \\
\hline 23 & Residues food industries & 0.00 & 5.71 & 5.06 & 39 & 0.01 & 6 \\
\hline 24 & Tobacco & 0.96 & 44.59 & 24.91 & 9491 & 2.89 & 41 \\
\hline 25 & Salt; sulphur, lime \& cement & 0.95 & 0.96 & 0.37 & 10958 & 3.34 & 44 \\
\hline 26 & Ores, slag and ash & & 0.00 & 0.00 & 26 & 0.01 & 2 \\
\hline 27 & Mineral fuels, mineral oils & 0.00 & 2.53 & 1.34 & 2 & 0.00 & 8 \\
\hline 28 & Inorganic chemicals & 1.00 & 4.67 & 2.00 & 57695 & 17.56 & 43 \\
\hline 29 & Organic chemicals & 0.31 & 4.42 & 2.83 & 11369 & 3.46 & 44 \\
\hline 30 & Pharmaceutical products & & 0.00 & 0.00 & 2785 & 0.85 & 48 \\
\hline 31 & Fertilisers & 1.00 & 4.29 & 2.23 & 26765 & 8.15 & 43 \\
\hline 32 & Tanning, paints and varnishes & 0.00 & 6.50 & 3.41 & 367 & 0.11 & 7 \\
\hline 33 & Essential oils and resinoids & 0.91 & 2.29 & 1.34 & 942 & 0.29 & 123 \\
\hline 34 & Soap & 0.93 & 2.31 & 1.16 & 572 & 0.17 & 39 \\
\hline 35 & Albuminoidal substances & 1.00 & 7.70 & 2.70 & 0 & 0.00 & 1 \\
\hline 36 & Explosives, pyrotechnic products & & & & & & \\
\hline 37 & Photographic & & & & & & \\
\hline 38 & Miscellaneous chemicals & 0.14 & 5.28 & 2.40 & 1165 & 0.35 & 33 \\
\hline 39 & Plastics & 0.86 & 6.06 & 3.65 & 3765 & 1.15 & 126 \\
\hline 40 & Rubber and articles & 0.00 & 3.11 & 1.98 & 7744 & 2.36 & 21 \\
\hline 41 & Raw hides and skins \& leather & 0.00 & 1.36 & 0.13 & 3217 & 0.98 & 10 \\
\hline 42 & Articles of leather & 0.01 & 4.28 & 2.89 & 19 & 0.01 & 20 \\
\hline 43 & Furskins and artificial fur & 1.00 & 3.70 & 2.36 & 22 & 0.01 & 1 \\
\hline
\end{tabular}


Wood products

Cork products

Manufactures of straw

Pulp of wood cellulosic material

Paper and paperboard

Printed books, newspapers

Silk

Wool, fine or coarse animal hair

$$
\text { Cotton }
$$

Other vegetable textile fibres

Man-made filaments

Man-made staple fibres

Wadding, felt and nonwovens

Carpets and other textile floor

Special woven fabrics

Impregnated, coated

Knitted or crocheted fabrics

Apparel \& clothing, knitted or crocheted

Articles of apparel \& clothing, not knitted or crocheted

Other made-up textiles articles

Footwear

Headgear

Umbrellas

Feathers \& down

Articles of stone, plaster, cement

Ceramic products

Glass and glassware

Pearls, precious stones, precious metals Iron and steel

Articles of iron or steel

Copper \& articles

Nickel \& articles

Aluminium \& articles

Lead \& articles

Zinc \& articles

Tin \& articles

Other base metals

Tools, cutlery, of base metal

Miscellaneous articles of base metal

Nuclear reactors, boilers

Electrical machinery \& equipment

Railway or tramway locomotives

Vehicles other than railway

Aircraft, spacecraft \& parts

Ships, boats \& floating structures

Optical, photographic, medical instruments

Clocks and watches and parts thereof
0.83

0.88

0.00

3.70

0.00

0.00

0.00

7.20

0.00

0.00

8.00

8.00

0.99

0.94

6.00

8.00

0.00

0.96

0.08

0.04

0.00

0.01

0.07

0.97

0.00

0.00

0.00

0.00

0.72

0.38

0.00

0.83

4.05

6.95

7.75

6.67

7.25

11.94

11.44

10.12

9.99

2.70

4.70

2.20

1.20

5.32

5.13

1.69

0.00

0.04

2.68

0.96

1.87

0.00

1.00

5.81

0.34

2.50

0.00

0.00

3.50

0.00

0.07

2.88

0.00

2.09

0.06

1.45

1.89

0.00

0.31

0.00

6.22

0.00

1.61

2.20

0.00

0.79

0.00
2.81
0.50

25

0.01

16

2.67

2

0.00

1

$\begin{array}{lccc}0.00 & 539 & 0.16 & 49 \\ 0.00 & 118 & 0.04 & 65 \\ 5.94 & 0 & 0.00 & 1 \\ 3.37 & 21 & 0.01 & 1 \\ 2.36 & 49 & 0.01 & 5\end{array}$

\subsection{1}

5.43

2.66

5.03

4.14

4.11

3.23

6.38

6.11

6.24

5.95

2.37

4.51

1.80

0.66

3.99

4.05

1.27

0.00

1.78

1.08

0.00

2.83

0.75

0.00

3.44

2.27

1.58

1.04

1.34

0.00

3.56

1.33

1.84

0.64

1.59

$\begin{array}{ccc}25 & 0.01 & 3 \\ 2 & 0.00 & 3 \\ 10 & 0.00 & 2 \\ 72 & 0.02 & 11 \\ 1 & 0.00 & 4 \\ 3 & 0.00 & 3 \\ 0 & 0.00 & 2 \\ 31294 & 9.53 & 285\end{array}$

$3321 \quad 1.01 \quad 301$

$4348 \quad 1.32 \quad 55$

$\begin{array}{lll}156 & 0.05 & 25\end{array}$

$\begin{array}{lll}2 & 0.00 \quad 7\end{array}$

$\begin{array}{lll}2 & 0.00 \quad 2\end{array}$

$\begin{array}{lll}1 & 0.00 \quad 1\end{array}$

$\begin{array}{lll}99 & 0.03 \quad 23\end{array}$

$24 \quad 0.01 \quad 21$

$25803 \quad 7.85 \quad 52$

$314 \quad 0.10 \quad 11$

$\begin{array}{lll}578 & 0.18 & 49\end{array}$

$\begin{array}{lll}7602 & 2.31 & 14\end{array}$

$\begin{array}{lll}30 & 0.01 \quad 1\end{array}$

$8709 \quad 2.65 \quad 35$

$3089 \quad 0.94 \quad 8$

$\begin{array}{lll}24 & 0.01 \quad 1\end{array}$

$\begin{array}{lll}18 & 0.01 \quad 2\end{array}$

$\begin{array}{lll}73 & 0.02 \quad 33\end{array}$

$210 \quad 0.06 \quad 29$

$62412 \quad 19.00 \quad 380$

$4807 \quad 1.46 \quad 374$

$\begin{array}{lll}152 & 0.05 \quad 2\end{array}$

$1032 \quad 0.31 \quad 44$

$\begin{array}{lll}1638 & 0.50 \quad 39\end{array}$

$\begin{array}{lll}37 & 0.01 \quad 2\end{array}$

$\begin{array}{lll}2496 & 0.76 \quad 205\end{array}$

$\begin{array}{lll}33 & 0.01 \quad 38\end{array}$ $\begin{array}{lll}92 & 0.03 & 23\end{array}$ 


\begin{tabular}{lccccccc}
92 & Musical instruments & 0.00 & 3.20 & 2.76 & 0 & 0.00 & 1 \\
93 & Arms and ammunitions & & & & & & \\
94 & Furniture; bedding mattresses & 0.08 & 2.03 & 1.65 & 641 & 0.20 & 67 \\
95 & Toys, games and sports requisites & 0.00 & 2.13 & 1.99 & 16 & 0.00 & 21 \\
96 & Miscellaneous manufactured articles & 0.49 & 3.70 & 2.92 & 1435 & 0.44 & 66 \\
97 & Works of art & & 0 & 0 & 46 & 0.01 & 21 \\
\hline & Total number of lines
\end{tabular}

Source: Eurostat for trade data and TRAINS for tariff data. Note: Blanks in column 3 indicate that all imports in that HS category have zero MFN duties. Blanks on column 4 indicate no data for tariff due to specific tariff. 
Table A4 Top 10 preferential margins: Imports and utilization rates (HS4) (2016)

\begin{tabular}{|c|c|c|c|c|c|c|c|c|c|}
\hline \multicolumn{5}{|c|}{ EU imports from Jordan } & \multicolumn{5}{|c|}{ USA imports from Jordan } \\
\hline HS4 & Description & $\begin{array}{c}\text { Adjusted } \\
\text { pref. } \\
\text { margin }\end{array}$ & $\begin{array}{l}\text { Import } \\
\text { value }(1000 \\
\text { euros })\end{array}$ & $\begin{array}{c}\text { Utilization } \\
\text { rate }\end{array}$ & HS4 & Description & $\begin{array}{l}\text { Adjusted } \\
\text { pref. } \\
\text { margin }\end{array}$ & $\begin{array}{l}\text { Import } \\
\text { value (1000 } \\
\text { USD) }\end{array}$ & $\begin{array}{l}\text { Utilization } \\
\text { rate }\end{array}$ \\
\hline 1510 & $\begin{array}{l}\text { Other oils and their fractions, obtained solely } \\
\text { from olives, whether or not refined }\end{array}$ & 62 & 0.3 & 0.00 & 7013 & $\begin{array}{l}\text { Glassware for table, kitchen, toilet, office, } \\
\text { indoor decoration or similar purposes nesoi }\end{array}$ & 25 & 3.0 & 1.00 \\
\hline 1701 & $\begin{array}{l}\text { Cane or beet sugar and chemically pure sucrose, } \\
\text { in solid form }\end{array}$ & 47 & 29.6 & 0.00 & 6111 & $\begin{array}{l}\text { Babies' garments and clothing accessories, } \\
\text { knitted or crocheted }\end{array}$ & 23 & 158.0 & 1.00 \\
\hline 1509 & $\begin{array}{l}\text { Olive oil and its fractions, whether or not } \\
\text { refined, but not chemically modified }\end{array}$ & 41 & 24.9 & 0.57 & 6911 & $\begin{array}{c}\text { Ceramic, tableware, kitchenware, other } \\
\text { household and toilet articles of porcelain or } \\
\text { china }\end{array}$ & 21 & 3.2 & 0.00 \\
\hline 2403 & $\begin{array}{l}\text { Other manufactured tobacco and manufactured } \\
\text { tobacco substitutes }\end{array}$ & 39 & 9476.8 & 0.96 & 6102 & $\begin{array}{c}\text { Women and girls' overcoats, car coats, } \\
\text { capes, , anoraks and similar articles, knitted } \\
\text { or crocheted }\end{array}$ & 20 & 61400.0 & 1.00 \\
\hline 1602 & $\begin{array}{l}\text { Other prepared or preserved meat, meat offal or } \\
\text { blood }\end{array}$ & 35 & 0.2 & 0.00 & 6101 & $\begin{array}{c}\text { Men's or boys' overcoats, car coats, capes, } \\
\text { anoraks and similar articles, knitted or } \\
\text { crocheted }\end{array}$ & 18 & 39400.0 & 1.00 \\
\hline 1101 & Wheat or meslin flour & 32 & 0.3 & 0.00 & 6114 & Other garments, knitted or crocheted & 17 & 6999.9 & 1.00 \\
\hline 1102 & Cereal flours other than of wheat or meslin & 25 & 5.7 & 1.00 & 6208 & $\begin{array}{c}\text { Women's or girls singlest and other vest, } \\
\text { slips, petticoats, briefs, panties, nightdresses, } \\
\text { pyjamas and similar articles }\end{array}$ & 16 & 5.5 & 1.00 \\
\hline 1103 & Cereal groats, meal and pellets & 25 & 8.5 & 0.89 & 6103 & $\begin{array}{l}\text { Men's or boys' suits, jackets, dresses, skirts, } \\
\text { trousers, knitted or crocheted }\end{array}$ & 16 & 49700.0 & 0.99 \\
\hline 1104 & $\begin{array}{l}\text { Cereal grains otherwise worked (for example, } \\
\text { hulled, rolled, flaked, pearled, sliced or kibbled), } \\
\text { except rice of heading 1006; germ of cereals, } \\
\text { whole, rolled, flaked or ground }\end{array}$ & 21 & 10.8 & 0.98 & 6105 & Men's or boys' shirts, knitted or crocheted & 16 & 95300.0 & 1.00 \\
\hline 1108 & Starches; inulin & 18 & 8.1 & 1.00 & 6104 & $\begin{array}{l}\text { Women's or girls' suits, jackets, dresses, } \\
\text { skirts, trousers, knitted or crocheted }\end{array}$ & 15 & 136000.0 & 1.00 \\
\hline
\end{tabular}


Source: Eurostat for trade data and TRAINS for tariff data for the EU; USITC for trade and tariff data for the USA.

Table A5: Exports > 2\% total: utilization Rates and preferential margins (HS4) (2016)

\begin{tabular}{|c|c|c|c|c|c|c|c|c|c|}
\hline \multicolumn{5}{|c|}{ Jordan exports to EU } & \multicolumn{5}{|c|}{ Jordan exports to USA } \\
\hline HS4 & Description & $\begin{array}{c}\text { Export } \\
\text { share }(\%)\end{array}$ & $\begin{array}{c}\text { Adjusted } \\
\text { pref. } \\
\text { margin }\end{array}$ & $\begin{array}{l}\text { Utilization } \\
\text { rate }\end{array}$ & HS4 & Description & $\begin{array}{c}\text { Export } \\
\text { share }(\%)\end{array}$ & $\begin{array}{c}\text { Adjusted } \\
\text { pref. } \\
\text { margin }\end{array}$ & $\begin{array}{l}\text { Utilization } \\
\text { rate }\end{array}$ \\
\hline 8411 & $\begin{array}{c}\text { Turbojets, turbopropellers and other gas } \\
\text { turbines }\end{array}$ & 16.0 & 1.3 & 0.00 & 6110 & $\begin{array}{l}\text { Jerseys, pullovers and similar articles, knitted } \\
\text { or crocheted }\end{array}$ & 30.8 & 13.8 & 1.00 \\
\hline 2834 & Nitrates & 10.5 & 0.2 & 1.00 & 6204 & $\begin{array}{l}\text { Women's or girls' suits, jackets, dresses, } \\
\text { skirts, trousers, not knitted or crocheted }\end{array}$ & 16.0 & 13.8 & 1.00 \\
\hline 2801 & Fluorine, chlorine, bromine and iodine & 5.2 & 0.1 & 1.00 & 6104 & $\begin{array}{l}\text { Women's or girls' suits, jackets, dresses, } \\
\text { skirts, trousers, knitted or crocheted }\end{array}$ & 9.2 & 14.8 & 1.00 \\
\hline 3105 & $\begin{array}{l}\text { Mineral or chemical fertilisers ; goods of } \\
\text { this chapter in tablets or similar forms or } \\
\text { in packages of a gross weight not } \\
\text { exceeding } 10 \mathrm{~kg}\end{array}$ & 4.8 & 3.2 & 1.00 & 7113 & Articles of jewellery & 8.1 & 2.9 & 1.00 \\
\hline 3104 & $\begin{array}{l}\text { Mineral or chemical fertilisers containing } \\
\text { two or three of the fertilising elements } \\
\text { nitrogen, phosphorus and potassium }\end{array}$ & 3.3 & 0.0 & & 6105 & Men's or boys' shirts, knitted or crocheted & 6.4 & 15.6 & 1.00 \\
\hline 6110 & $\begin{array}{l}\text { Jerseys, pullovers and similar articles, } \\
\text { knitted or crocheted }\end{array}$ & 3.3 & 5.5 & 0.00 & 6102 & $\begin{array}{c}\text { Women's or girls' overcoats, car coats, capes, } \\
\text { anoraks and similar articles, knitted or } \\
\text { crocheted }\end{array}$ & 4.1 & 20.1 & 1.00 \\
\hline 2510 & $\begin{array}{l}\text { Natural calcium phosphates, natural } \\
\text { aluminium calcium phosphates and } \\
\text { phosphatic chalk }\end{array}$ & 3.1 & 0.0 & & 6203 & $\begin{array}{l}\text { Men's or boys' suits, jackets, dresses, skirts, } \\
\text { trousers, not knitted or crocheted }\end{array}$ & 3.7 & 12.6 & 1.00 \\
\hline 7108 & $\begin{array}{l}\text { Gold (including gold plated with } \\
\text { platinum), unwrought or in semi- } \\
\text { manufactured forms, or in powder form }\end{array}$ & 3.1 & 0.0 & & 6103 & $\begin{array}{l}\text { Men's or boys' suits, jackets, dresses, skirts, } \\
\text { trousers, knitted or crocheted }\end{array}$ & 3.4 & 15.7 & 0.99 \\
\hline 2403 & $\begin{array}{l}\text { Other manufactured tobacco and } \\
\text { manufactured tobacco substitutes }\end{array}$ & 2.9 & 39.0 & 0.96 & 6109 & $\begin{array}{l}\text { T-shirts, singlets and other vests, knitted or } \\
\text { crocheted }\end{array}$ & 3.2 & 11.8 & 0.99 \\
\hline 7112 & Waste and scrap of precious metal & 2.9 & 0.0 & & 6101 & $\begin{array}{c}\text { Men's or boys' overcoats, car coats, capes, } \\
\text { anoraks and similar articles, knitted or } \\
\text { crocheted }\end{array}$ & 2.7 & 17.8 & 1.00 \\
\hline
\end{tabular}




\begin{tabular}{|c|c|c|c|c|c|c|c|c|}
\hline 6109 & $\begin{array}{l}\text { T-shirts, singlets and other vests, knitted } \\
\text { or crocheted }\end{array}$ & 2.6 & 4.0 & 0.00 & 3004 & Medicaments & 2.6 & 0.0 \\
\hline 7404 & Copper waste and scrap & 2.3 & 0.0 & & & & & \\
\hline 2933 & $\begin{array}{l}\text { Heterocyclic compounds with nitrogen } \\
\text { hetero-atom(s) only }\end{array}$ & 2.2 & 3.2 & 0.00 & & & & \\
\hline 0709 & Other vegetables, fresh or chilled & 2.2 & 4.6 & 1.00 & & & & \\
\hline 4011 & New pneumatic tyres, of rubber & 2.1 & 3.1 & 0.00 & & & & \\
\hline
\end{tabular}

Source: Eurostat for trade data and TRAINS for tariff data for the EU; USITC for trade and tariff data for the USA 

"Sur quoi la fondera-t-il l'économie du monde qu'il veut gouverner? Sera-ce sur le caprice de chaque particulier? Quelle confusion! Sera-ce sur la justice? Il l'ignore."

Pascal



Created in 2003, the Fondation pour les études et recherches sur le développement international aims to promote a fuller understanding of international economic development and the factors that influence it.

\section{$\hookrightarrow$ Contact}

www.ferdi.fr

contact@ferdi.fr

+33 (0)4 73177530 